Article

\title{
A Comparative Study of Traditional and Contemporary Building Envelope Construction Techniques in Terms of Thermal Comfort and Energy Efficiency in Hot and Humid Climates
}

\author{
Pooya Lotfabadi *iD and Polat Hançer \\ Faculty of Architecture, Eastern Mediterranean University, Famagusta 99628, North Cyprus, \\ via Mersin 10, Turkey \\ * Correspondence: pooya.lotfabadi@gmail.com or pooya.lotfabadi@cc.emu.edu.tr; Tel.: +90-533-871-8887
}

Received: 15 May 2019; Accepted: 24 June 2019; Published: 28 June 2019

\begin{abstract}
Expectations of traditional and contemporary buildings are different in terms of thermal comfort. Traditional buildings mostly achieve comfort through passive means, without HVAC support, but old levels of thermal satisfaction do not meet today's expectations, although their passive thermal performances are notable for contemporary building designs. In this regard, the current study tries to investigate the possibility of comparing traditional and contemporary buildings' construction techniques to achieve thermal comfort from an architectural point of view. In other words, is it possible to achieve passive building design by considering vernacular architecture principals as a reference? Likewise, how well can architects define insulation layers in contemporary construction surfaces in hot and humid climates? To this end, a dynamic, numerical, thermal calculation case study has been modeled in Famagusta, Northern Cyprus, to answer the above-mentioned questions. A mixed-use mode benefitting free-run periods is proposed and compared with a mode providing 24 hours of air-conditioning in different scenarios using the same initial settings. Thus, different floor-to-ceiling heights, insulation placements and indoor conditions have been tested separately in both winter and summer periods. The results show that thermal comfort can be achieved in free-run periods only during a limited percentage of the year. Furthermore, although increasing building heights may lead to a rise in the free-run periods, in contemporary buildings it increases the total energy usage of the buildings between $6 \%$ and $9 \%$ in the mixed mode. Therefore, vernacular architecture strategies are proper in their own context. However, this energy usage can still be controlled and optimized by such considerations as insulation material placement. In this regard, the best envelope properties for different building functions are proposed for application in hot and humid climates.
\end{abstract}

Keywords: thermal comfort; floor-to-ceiling height; insulation placement; material properties; vernacular architecture

\section{Introduction}

Buildings are expected to create permanent healthy and comfortable indoor conditions, regardless of outdoor climate conditions. Apart from the high energetic performance of building envelopes, this issue places certain demands on heating and cooling energy to make a building thermally comfortable, and a building's energy consumption comprises $20-40 \%$ of total energy demand [1-6].

In general, buildings absorb thermal energy through convection and radiation from the outdoor environment [7]. Its intensity depends on several parameters, such as number of surfaces and their area, materials' heat capacities and massiveness, thermal conductivity, density, and thickness, and so 
on $[8,9]$. In this regard, one of the most effective parameters is a building's surface dimensions. In other words, based on heat transfer principles, the thermal inertia of a building is directly dependent on its volume $[7,10]$. Therefore, for this reason, building standards and regulations allow designers to reduce ceiling heights and decrease surface sizes [11], while influencing indoor air temperature and reducing the indoor environment's thermal inertia.

However, this is in contrast with vernacular architecture [12]. According to empirical observations, building height has a direct effect on indoor air temperature [11], since in higher environments, the air volume is greater. This law of physics is especially beneficial in hot and humid climates such as Northern Cyprus, which suffers from hot seasons. In other words, this principal leads hot weather away from building occupants. Furthermore, the sizes and heights of fenestrations are another consideration for ventilating and subtilizing internal temperature [13].

Different aspects of human comfort conditions have been investigated previously [8,13-15]. Therefore, this paper commences by exploring the influence of changing the floor-to-ceiling height on occupants' thermal satisfaction for displacement ventilation under certain indoor conditions. The initial hypothesis is that higher ceilings create more vertical temperature differences [9], which has a positive effect on the sense of thermal comfort in summer, especially in hot and humid climates. On the other hand, this increment leads to more thermal comfort satisfaction due to natural displacement ventilation and increasing free-run periods [16]. A free-run period is a time period in which no energy is supplied by heating/cooling systems, and the air change rate is considered to be at its nominal value [17]. In other words, the building reaches a comfort level just by virtue of its natural ventilation, without any air conditioning system. Thus, higher ceilings might save more energy by reducing the air supply volume to an equal internal load. However, based on recent developments in construction techniques, an improved level of comfort satisfaction has been achieved. Therefore, instead of using massive thermal masses, insulation properties can be applied. Thus, the next step is testing the best place for insulation materials to be applied in the aforementioned climate.

To sum up, this research attempts to evaluate the applicability of vernacular architecture principals in contemporary buildings as a construction technique. The study attempts to compare Cypriot vernacular architecture with contemporary architecture, and cases of floor-to-ceiling height and insulation placement, in order to develop material properties and improve indoor thermal conditions by proposing applicable free-run periods and evaluating different air-conditioning scenarios in hot and cold seasons separately.

One of the main concerns of human beings presently is global warming and the decrease of natural resources [18]. These concerns are intensified by population growth, which also leads to an increase of $\mathrm{CO}_{2}$ emissions [19]. On the other hand, in developed countries, inhabitants spend almost $90 \%$ of their time indoors [20], which shows the importance of creating comfortable conditions in buildings. In other words, today's world faces serious energy problems. In this regard, the building industry plays a significant role. It accounts for more than $40 \%$ of the world's total energy consumption [21,22]. One of the main aims of this vast usage is to provide satisfying thermal comfort and an acceptable indoor air quality for residents. However, several field studies have recorded considerable rates of thermal comfort dissatisfaction [23-25]. This dissatisfaction may be caused by thermal discomfort of the whole body, which can be expressed further with the predicted mean vote (PMV) and predicted percentage of dissatisfied (PPD) indices. It may also be caused by unwanted heating/cooling of a particular part of the body [26,27].

For a long time, minimizing buildings' energy consumption while maximizing comfort conditions has been a serious goal in architecture and urban planning. Designs in different climate zones have been developed in order to gain maximum solar exposure for buildings located in cold climates, and reducing solar exposure and increasing natural ventilation for buildings in hot climates [28-30]. In this regard, Cypriot vernacular architecture has achieved a reliable means of countering local climatic situations by shaping buildings and city textures. 
Cyprus is the third-largest island in the Mediterranean Sea, located in its north-eastern corner. It is estimated that the creation of the earliest settlements on the island dates back to the 8th century B.C. [31]. Generally, the island climate is Mediterranean with local variations, which can be categorized as a hot and humid climate with hot summers and cold winters. In this case, the climate has been one of the most influential elements in forming cities and their architectures in this region [32]. Therefore, the response of Cypriot ancestors has been reflected in their vernacular architecture.

Although it seems obvious, comfort does not have a specific definition. Unfortunately, it is somehow a nebulous concept and can change from one person to another. Thermal comfort is a kind of condition in which a person subjectively feels satisfaction with their thermal environment [33]. It can be understood from this definition that the terms satisfaction and mind (subjective feelings) are somehow unpredictable variables. According to these types of uncertainty, the kernel of comfort can be considered as a phenomenological notion [34]. However, simultaneously, it also emphasizes that assessing thermal comfort is a cognitive process involving several parameters, and which is also influenced by physiological, psychological, physical and other processes [35].

In the case of assessing thermal indoor comfort, it should be considered that an occupant does not feel the room temperature; he/she feels the loss of body heat. Thus, the environmental parameters affecting the energy loss are those that must be measured. The main environmental parameters can be identified as air temperature, air flow/movement, humidity, and radiation or mean radiant temperature. The effect of the mentioned parameters is not equal on the body's energy loss, so when assessing thermal comfort, it is not adequate to only consider and evaluate one parameter [36].

In the 1960s, bioclimatic design was innovated by the Olgyay brothers. They combined bioclimatology with architecture by considering users' thermal comfort. In the case of adapting architects to the climate, they also developed a bioclimatic diagram [37]. Later, based on psychometrics principles, Givoni tried to correct Olgyay's diagram limitations and redeveloped the diagram [11].

Olgyay's bioclimatic chart has a constant comfort in the range from 20 to $30{ }^{\circ} \mathrm{C}$. This level of comfort can be applied to indoor spaces with an indoor level of clothing. The maximum and minimum air temperatures and the corresponding minimum and maximum relative humidity values are the necessary climatic data to design the bioclimatic charts, either monthly, daily or hourly [38]. The resultant graphs display the external conditions. Even though the indoor environmental conditions of the building are influenced by many other factors, such as building size, material thermal inertia and so on, the charts clearly demonstrate whether indoor conditions are comfortable or not. The most efficient role of this chart and its graphs is that the heating and cooling design strategies are determined so as to be able to restore comfort throughout the whole year [39].

At the center of the bioclimatic chart, the comfort zone is presented. The chart considers the levels of comfort that are combined with ranges of other climatic factors, such as wind speed, solar radiation and mean radiant temperature, which can be felt outside the comfort zone. To maintain an acceptable level of comfort, shading is necessary above the boundary of the zone. As long as there is enough solar radiation to offset the decrease in temperature, comfort can be retained at up to $10{ }^{\circ} \mathrm{C}$ below the comfort zone. Furthermore, wind speed can compensate for an increase in temperature to retain comfort at up to around $10{ }^{\circ} \mathrm{C}$ above the comfort zone. According to this chart, evaporative cooling is another means to retain comfort at high temperature and low humidity [40].

Additionally, it should be mentioned that various methods have been applied in order to achieve comfortable indoor environments. The most acceptable is based on the 1960s doctoral thesis of Danish scientist, Ole Fanger [41]. He tried to consider all relevant physical factors in his studies, in order to enhance knowledge about individuals' thermal comfort. According to laboratory steady-state conditions, he claimed that parameters such as mean radiant temperature $\left(T_{r}\right)$, air temperature $\left(T_{a}\right)$, air velocity around the human body $\left(\mathrm{V}_{\mathrm{a}}\right)$, ambient water vapor pressure or relative humidity $(\mathrm{RH})$, which can be combined with activity level $(\mathrm{M})$ and thermal resistance of inhabitants' clothing $\left(I_{c l}\right)$, are the main factors. Overall, these factors can make approximately $90 \%$ of occupants comfortable 
and can be combined to generate one variable named the PMV [42]. The first four variables are environmental factors, while the last two variables are personal factors [43-45].

The heat-balance equation and empirical studies regarding skin temperature are utilized by the PMV to define thermal comfort. Subjects are asked about their thermal sensation on a seven-point scale from cold $(-3)$ to hot $(+3)$ in standard thermal comfort surveys. In this case, zero demonstrates thermal neutrality, which is the idle value. PMV is determined through the following equation [46]:

$$
\begin{gathered}
\mathrm{PMV}=\left[0.303 e^{-0.036 \mathrm{M}}+0.028\right]\left[(\mathrm{M}-\mathrm{W})-3.96 E^{-8} f_{c l}\left[\left(t_{c l}+237\right)^{4}-\left(t_{r}+237\right)^{4}\right]-f_{c l} h\left(t_{c l}-t_{a}\right)-\right. \\
\left.3.05\left[5.73-0.007(\mathrm{M}-\mathrm{W})-\rho_{a}\right]-0.42[(\mathrm{M}-\mathrm{W})-58.15]-0.0173 \mathrm{M}\left(5.87-\rho_{a}\right)-0.0014 \mathrm{M}\left(34-t_{a}\right)\right]
\end{gathered}
$$

where $e$ is Euler's number (2.718), $h_{c}$ is the coefficient of convective heat transfer, $\rho_{a}$ is air vapor pressure and $\mathrm{W}$ is external work $(0)$.

Therefore, the comfort zone is defined by the combinations of the mentioned six parameters for which the PMV is within the recommended limits $(-0.5<$ PMV $<+0.5)$. Meanwhile, this experiment is based on the fact that individuals feel their indoor environment differently. However, although a steady-state situation is assumed, the minority experience is less than a comfortable state [43].

Likewise, he found that the predicted vote was merely the mean value, which is expected from a group of people, and he extended the PMV to predict the ratio of different populations who may not be content with the environment. A person's comfort was defined through dissatisfaction. On ASHRAE, the people who voted outside the central three scaling points were counted as discontent. PPD does not add any information to that already available and is defined in terms of PMV. The observations from climate chamber experiments, rather than field measurements, are the basis of the distribution of $\operatorname{PPD}[23,46]$.

Thermal comfort is measured by PPD through the prediction of the percentage or number of occupants who will not be satisfied with the thermal conditions of the room. Thus, PPD is a function of PMV and is directly calculated from PMV [47]. The process for determining PPD is almost the same as for PMV. In other words, this process involves selecting the ranges of each independent variable, choosing input values for each independent variable, selecting the independent variables' distribution, then selecting a sample for the chosen distributions, and finally putting the values of each independent variable into the PMV model. When carrying out the research, this process will be followed. After specifying the PMV value, PPD can be calculated by using the equation below [46]:

$$
\mathrm{PPD}=100-95 e^{-\left(0.3353 P M V 4+0.2179 P M V^{2}\right)}
$$

After Fanger's hypothesis, the evaluation of indoor thermal comfort is mainly based on his method, by measuring the PMV and, as a result, the PPD indices. This method is also accepted by several building standards, such as ISO 7730 and ASHRAE 55 [33,48-52]. In this case, when PMV is in the range of -0.5 to 0.5 and PPD is less than $10 \%$, the thermal acceptability comfort situation can be reached in an air-conditioned building. However, the comfort situation in different regulations is classified in different groups, such as A, B and C in European regulations [33,35,50,53].

Furthermore, another way of evaluating thermal comfort is by using an adaptive method. Such methods are mainly used for areas with a monthly mean radiant temperature between 10 and $33.5^{\circ} \mathrm{C}$. For naturally ventilated spaces, the model can be defined as; $T_{\text {comf }}=0.31 \times T_{\text {ref }}+17.8$, in which $T_{\text {comf }}$ is the indoor comfortable operative temperature and $T_{r e f}$ is the prevailing mean outdoor temperature for the past 30 days. Meanwhile, similar to the Fanger model, ASHRAE accepts $80 \%\left(T_{\text {comf }} \pm 2.5^{\circ} \mathrm{C}\right)$ for typical applications, which theoretically increases the range of acceptable thermal comfort in comparison to the Fanger model [54]. However, observations of authors displayed that this new range is not acceptable in Cypriot culture [13]. Another limitation of this model is that it is mainly applicable to daytime period evaluations [33].

Based on the mentioned regulations, some researchers undertook evaluations by testing full-scale case studies. Huang Zhijun et al. [55] evaluated a gymnastics stadium in three different summer, 
winter and transitional season days with 221 temperature sensors. Krüger and Givoni [56] followed the thermal behavior throughout the year in a residential home. Both studies show the relationship between internal and external temperatures, which relates to other variables such as climate and materials.

These studies have been continued and developed by recent computer-aided techniques in order to generate more detailed and accurate results. In this regard, Hashimoto and Yoneda [57] compared various ceiling heights and their effects on thermal loads. This study showed that buildings with higher ceilings are much closer to the comfort zone [57]. AlOtaibi [46] used a computational fluid dynamics (CFD) software method in his research in order to model and simulate the thermal comfort in an office building. There, he concluded that altering ceiling height (by lowering the ceiling $2.4 \mathrm{~m}$ ) has a significant effect on the temperature distribution and thermal comfort level in an office building by utilizing an underfloor air distribution system.

Other relevant research with CFD-based analysis shows the direct relationship of temperature stratification with increasing the floor-to-ceiling height [11,36,37]. Aflaki et al. [58] studied the effect of total building heights on the indoor air temperature and velocity in high-rise buildings, and indicated how building height may influence indoor thermal conditions. They showed that indoor wind in the upper floor is almost four times higher than in the lower floor. Other researchers investigated the effect of building height on outdoor thermal comfort during the daytime in order to mitigate heat stress in summer $[59,60]$. However, although several conclusions may be applied to other cases, the results of each one represents a specific context.

In this regard, in order to create an architectural space, floor and ceiling are two indispensable parameters. In the formation of vernacular architecture, the floor-to-ceiling height and ceiling form are influenced by several variables, such as climate, natural environment, local materials, construction technologies, and so on [61]. Moreover, in order to achieve thermal comfort in the construction sector, thermal insulation is one of the most important factors [62,63]. Thermal insulation can lower heat transfer rates between controlled indoor areas and uncontrolled outdoor environments, leading to a significant reduction in building heating and cooling energy demands. However, previous studies have mainly been limited to considering insulation materials, such as cellulose, glass wool, rock wool, polystyrene, urethane foam and so on [64], or materials with low thermal conductivity coefficients or that are diffusivity adapted for reducing energy consumption [65,66]. For instance, Stazi et al. [67] and Hens et al. [68] studied the energy performance of cavity walls in a hot and humid climate.

Furthermore, some studies have considered the optimization of the building envelope construction type and the selection of the insulation level for walls, roofs, floors $[69,70]$ and/or chimney-roof penetrations [71-74]. Some of these researchers also discussed insulation thickness [75-79]. Neri et al. [80] analyzed the effect of phase change materials (PCM) on indoor temperatures. Moreover, Sambu et al. [81] studied the effect of wall thickness on energy efficiency, while Abanto et al. [82] tested this effect in adobe as a traditional material. Thus, research to date has mainly concentrated on selecting insulation materials [83], and a lack of information about proposing a method to select insulation placement can be considered a gap for designers.

Additionally, intense solar radiation, which causes high temperatures along with a high rate of humidity, are the main source of thermal discomfort in Cyprus. Therefore, in order to create a comfort zone, protecting a building and its elements from direct solar radiation with shading devices to avoid heat gain within the building envelope is one of the main considerations [84]. On the other hand, a case study of Famagusta, a coastal city in Cyprus with a high percentage of humidity, highlighted the need to create proper air circulation by using natural ventilation as another important factor.

Meanwhile, in the vernacular architecture of hot climates, such as in Cyprus, the walls are built very thick with special materials with low thermal conductivity, such as mud and limestone (Table 1). Therefore, there are some benefits for these considerations. For instance, low thermal diffusivity and low thermal conductivity increase the delay between absorbing heat from the outside surface of a wall and conducting it to the other side, leading to more comfortable interior conditions in the buildings. This is particularly significant given the $9-11^{\circ} \mathrm{C}$ yearly diurnal temperature variations in Famagusta, 
which shows the necessity of indoor temperature stability for creating a comfort zone $[61,85]$. For this reason, using low thermal conductivity and diffusivity materials helps to reduce the temperature swing between day and night. Because of this transformation, walls are cooler than human skin during the day. Hence, the human body will radiate in outside weather conditions [86].

However, over the centuries, building heights were lowered, opening sizes were reduced and materials were changed (Table 1). Unfortunately, these limestone and adobe houses are currently facing oblivion due to changes in lifestyle and shifting priorities. They, however, present a case from which lessons can be learnt and adopted in modern contexts for a meaningful and appropriate architecture in the region.

\section{Methodology}

In general, this research is based on a theoretical approach supported mainly by the outcomes of a literature review and case study analysis. On the other hand, it involves simulation analysis and, more particularly, a literature survey as a combination of two main phases, namely, the qualitative and quantitative methods of data collection (Figure 1). Generally, the integration of building information modeling (BIM) with other tools has major potential for sustainability assessment of buildings and is a subject addressed by numerous authors. However, this integration faces several barriers, such as the lack of interoperability between the different approaches and the need for a common data format. Thus, several distinctive energy simulation programs can be tested, each using a different level of modeling complexity. Unfortunately, however, not all the tests match these energy simulation programs. Thus, related to this issue, the Standard Method of the Test (SMOT), suggested by the ASHRAE, is utilized here in order to distinguish predictive differences of the DesignBuilder energy simulation software.

DesignBuilder 3.1.0.080 Beta is the software selected for this study, and it benefits from the EnergyPlus 7.2 simulation engine and the standard $k-\varepsilon$ turbulence model for CFD calculation. In this case, several studies have used and been advised by EnergyPlus in various fields [87-91]. There are various methods to examine the simulation program's validation, such as full-scale experimental study, small-scale experimental study, numerical methods, and so on. However, comparison between computational results and experimental data is the common validation method. If the simulation results generally agree with the experimental data, the results are declared as validated [92,93].

It should be mentioned that the validation of the simulated program had been tested in previous research [13]. The authors examined indoor natural ventilation experimentally and numerically, thus it can be an acceptable experimental test to evaluate software results in terms of natural ventilation. The results of comparing the simulated results with physical on-site measurements show a difference of approximately $3 \%$, which is acceptable for the simulation software. In this research, all initial simulation inputs and settings are also considered to be the same as in a previous study, which investigated the annual energy consumption of an office building in Iran using the same version of DesignBuilder, and which validated the results using the actual values. The comparison of actual energy usage and program estimation in 2015 showed a 1.6\% difference, which is acceptable [94].

A method testing the evaluation calibration methods (SMOT) was applied to adjust building energy models along with measured energy consumption data. This process also uses calibration methods by applying computer software, which predicts the energy performance of buildings. This makes it possible for the users to construct their own test models and specifications. The test model can be useful in several ways, such as: (1) It tests a single calibration method to find out how well it works under different test conditions; (2) it tests several calibration methods to see when each one gives the best result under different conditions; (3) it investigates the type and quantity of information content that is needed in the synthetic data in order to achieve better calibrations using different calibration methods (e.g., monthly vs daily vs hourly data, and availability of disaggregated data or different types of sub-metered data); (4) it tests different kinds and amounts of noise in the synthetic data; and (5) diagnostic testing. 
Table 1. Cypriot vernacular architecture through time.

\begin{tabular}{|c|c|c|c|c|c|}
\hline \multirow{2}{*}{ Time Periods } & Venetian & Ottoman & & British Colonial Period & Contemporary \\
\hline & $1192-1571$ & 1571-1878 & & $1878-1960$ & From 1983 \\
\hline \multicolumn{6}{|l|}{ Outdoor View } \\
\hline \multicolumn{6}{|l|}{ Indoor view } \\
\hline Construction materials & $\begin{array}{l}\text { Adobe, Sandstone, } \\
\text { Limestone, Timber }\end{array}$ & Sandstone, Limeston & imber & $\begin{array}{l}\text { Sandstone, Limestone, } \\
\text { Timber, Concrete }\end{array}$ & Reinforced Concrete, Break \\
\hline $\begin{array}{c}\text { Approximate Ceiling to } \\
\text { Ground Height }\end{array}$ & $\sim 5.9 \mathrm{~m}$ & $\sim 4.7-5.4 \mathrm{~m}$ & & $\sim 4.1 \mathrm{~m}$ & $2.6-3.5 \mathrm{~m}$ \\
\hline Materials & $\begin{array}{c}\text { Conductivity } \\
(\mathrm{W} / \mathrm{m}-\mathrm{K})\end{array}$ & $\begin{array}{l}\text { Specific Heat } \\
(\mathrm{J} / \mathrm{kg}-\mathrm{K})\end{array}$ & $\begin{array}{l}\text { Density } \\
\left(\mathrm{kg} / \mathrm{m}^{3}\right)\end{array}$ & $\begin{array}{c}\text { Thermal Absorptance } \\
\text { (Emissivity) }\end{array}$ & $\begin{array}{l}\text { Thermal Diffusivity } \\
\left(\mathrm{m}^{2} / \mathrm{s}\right)\end{array}$ \\
\hline $\begin{array}{c}\text { Adobe } \\
\text { (Soil, Earth, Common) }\end{array}$ & 1.280 & 880 & 1460 & 0.900 & $9.9 \times 10^{-7}$ \\
\hline Adobe with Straw & 1.800 & 609 & 1640 & 0.910 & $1.8 \times 10^{-6}$ \\
\hline Sandstone & 2.320 & 710 & 2150 & 0.970 & $1.17 \times 10^{-6}$ \\
\hline Limestone & 1.280 & 909 & 2750 & 0.960 & $6.2 \times 10^{-7}$ \\
\hline Timber & 1.300 & 2500 & 850 & 0.870 & $8.2 \times 10^{-8}$ \\
\hline Concretes & 2.270 & 837.36 & 2321.40 & 0.920 & $1.2 \times 10^{-6}$ \\
\hline Brick & 0.840 & 800 & 1700 & 0.860 & $6.1 \times 10^{-7}$ \\
\hline
\end{tabular}




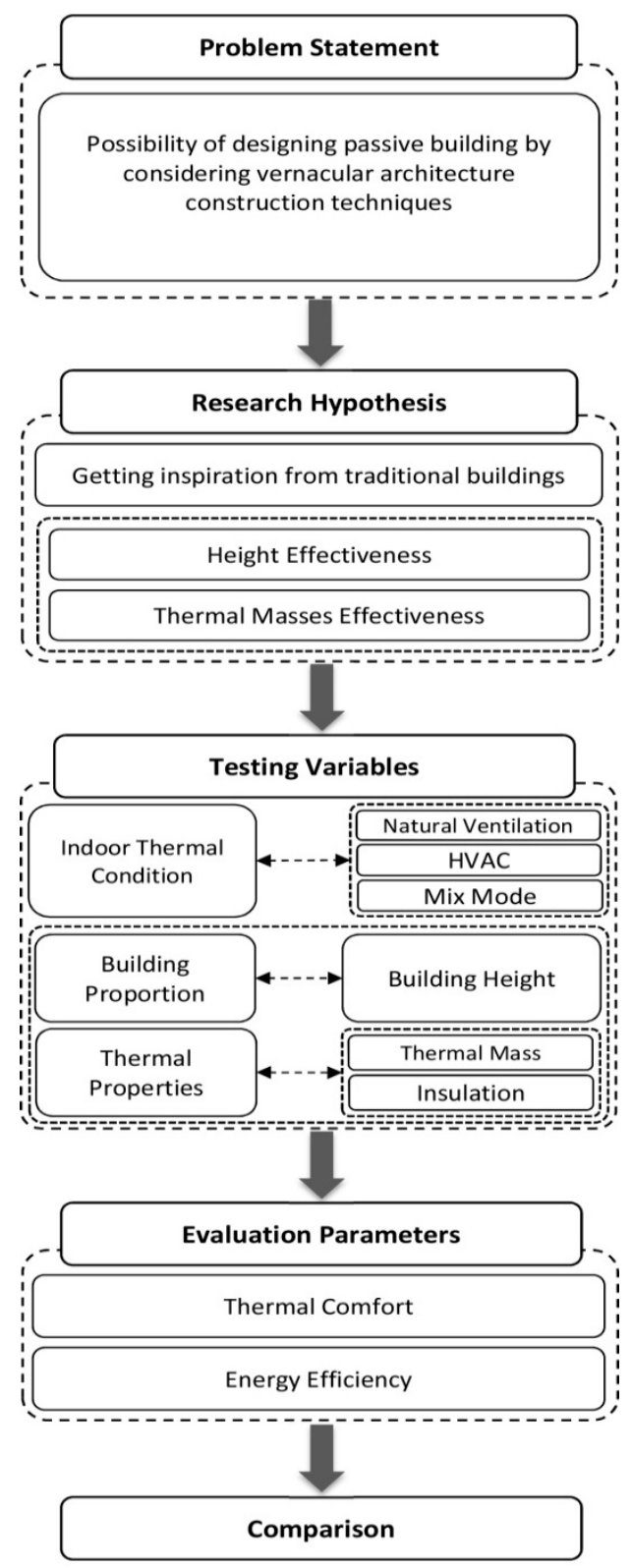

Figure 1. Research methodology assessment.

In this case, a method was characterized with the aim of creating a model without furniture in Famagusta, Northern Cyprus. As is illustrated in the next figure, the research started with modeling the case studies (Figure 2). This was also the case for defining the simulation model border and height. Then, in order to be able to compare the vernacular and contemporary buildings, a case study with vernacular materials (adobe) and techniques was modeled. This model was compared with four different models, which were designed based on contemporary construction techniques. In this regard, one case was modeled without insulation, which is more common in Cyprus, and the others were modeled with the same materials and wall thickness, insulated in different layers (Figure 3).

The next step was to define the optimum thermal comfort situation for each model and to calculate their energy performance in different ventilation scenarios. These scenarios were $24 \mathrm{~h}$ air-conditioning, day-time ventilation and night-time ventilation. This was done in order to understand the effect of free-run periods in different types of buildings with different functions, which need to be air-conditioned at different times. Here, it should be mentioned that based on Northern Cyprus regulations, the acceptable range of ceiling height for a one-story building is 2.6 to $3.5 \mathrm{~m}$. Therefore, 
in this research, these two heights were considered as the minimum and maximum building heights, and the described process was tested for both heights to analyze the effect of height on creating a more sustainable thermal zone. Then, the optimum energy performance for each of the mentioned conditions was selected. This process is explained completely in the next section. Finally, the results are presented for both summer time and winter time to evaluate the effectiveness of the research hypothesis in heating and cooling periods separately, as well as for a whole year, and then the results are compared. Furthermore, this research tried to identify a model to investigate the certain times of a year in which a free-run period should occur for energy consumption. To achieve this purpose, the authors simulated a whole year to find the thermal conditions of the building. Then, the possibility of achieving thermal comfort by using free-running was evaluated. Later, these periods are eliminated in the energy calculations.

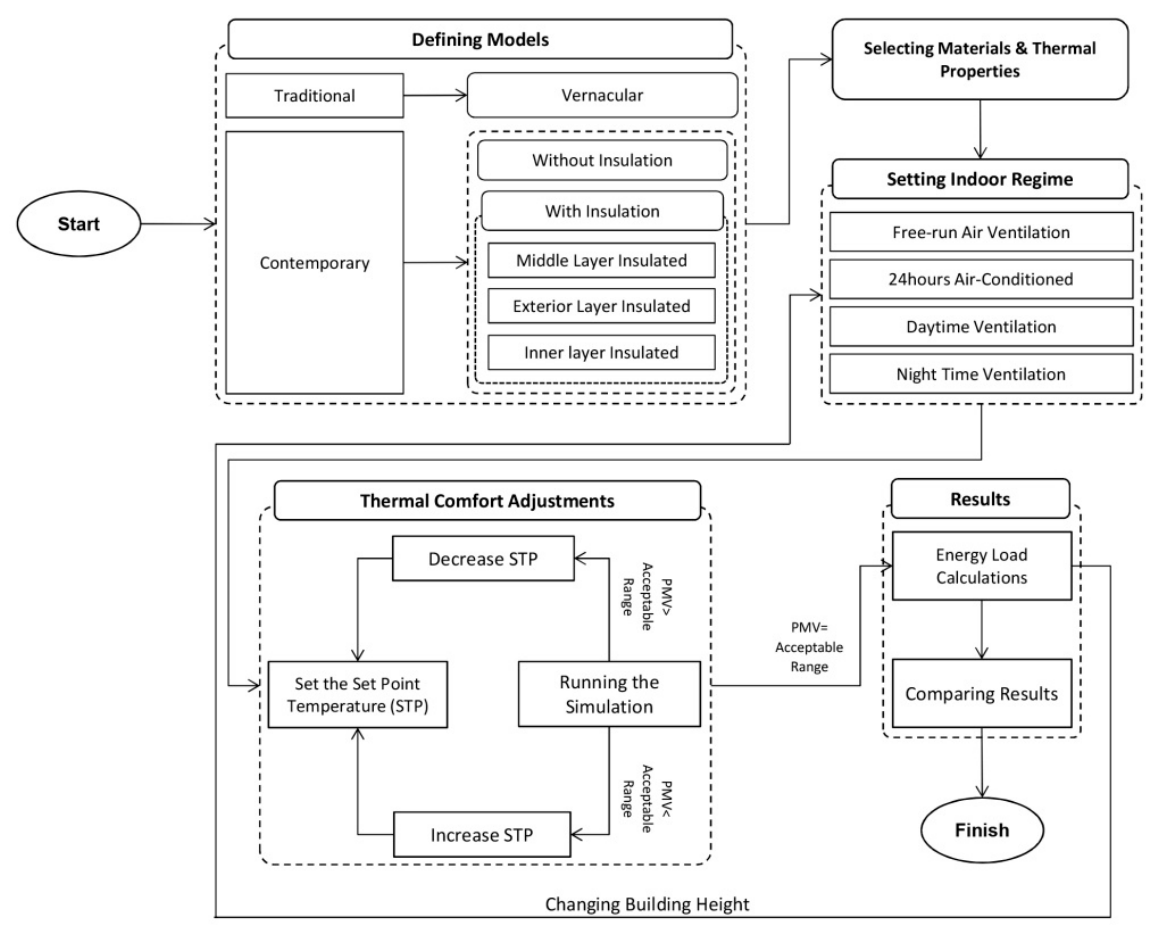

Figure 2. Evaluation process.
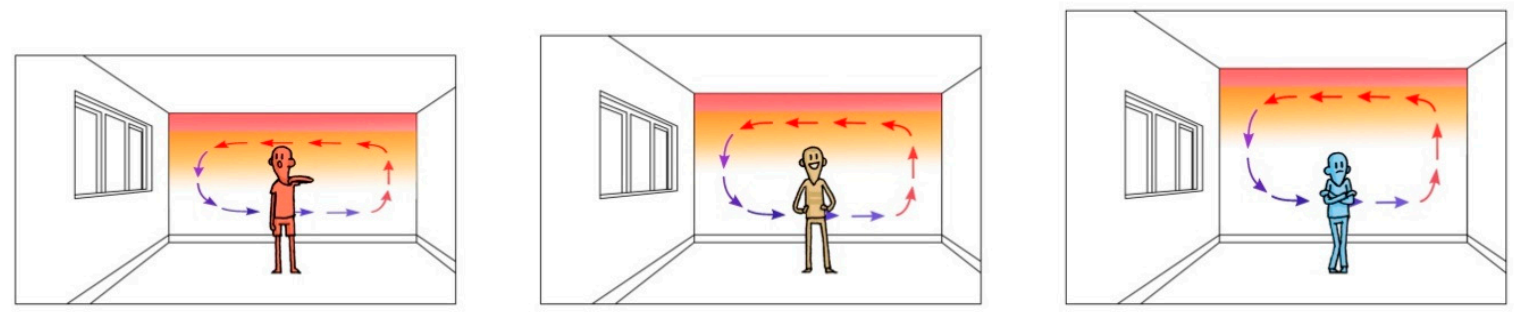

Figure 3. Position of hot air layers in the environment in the upper region.

\section{Case Study Analysis}

This research focuses on Famagusta's buildings as a case study. This city, with a population of about 54,000 [85], is the third-biggest city of Northern Cyprus. Famagusta is located at $35^{\circ} 7^{\prime} \mathrm{N}$ and $33^{\circ} 55^{\prime} \mathrm{E}$, and is $25 \mathrm{~m}$ above sea level. According to the Köppen-Geiger climate classification, it has a hot Mediterranean/dry-summer subtropical climate that is mild with moderate seasonality. In other words, due to the systems of subtropical high pressure, it is hot and dry in summer and, due to the polar front, it has rainy and moderate weather. Furthermore, the average maximum temperature in the 
hot season is approximately $33^{\circ} \mathrm{C}$ in the city. Meanwhile, the average minimum temperature for the cold season is about $17^{\circ} \mathrm{C}[95]$.

Currently, the Cypriot chamber of architects considers a building with a floor-to-ceiling height of 2.6 to $3.5 \mathrm{~m}$ to be a one-story building. Building contractors prefer to use the minimum height of $2.6 \mathrm{~m}$, which they believe leads to lower construction expenses, lower building energy usage and improved comfort conditions when in operation. However, traditionally, Cypriot architecture followed the reverse logic, such as during the Ottoman period. However, this floor-to-ceiling height was reduced over time during the British period and even more in contemporary architecture, mostly because of expenses (Table 1).

There is no doubt that solar radiation is very intense in Northern Cyprus. This intense radiation and high air temperature are the main reasons for discomfort in summer, which may have led to designing buildings with lower heights. However, But as this city is a coastal city, in order to create more comfortable zones, the humidity factor should be also controlled by natural ventilation. This factor needs a greater building height with bigger openings. In addition, traditional Cypriot architects understood the fact that by air convection, through natural air movement, hot masses with lower densities tend to rise. Temperatures in the higher levels tend to be higher within the space. Thus, this research attempted to evaluate the trustworthiness of the hypothesis that increasing the building height may lead to increasing the distance of the hot air layers from the building occupants, requiring less energy consumption to make a comfortable zone for users in summer, which is more critical rather than winter (Figure 3).

As was mentioned, five types of case studies have been modeled in this study (Figures 4 and 5). These cases considered as medium prototypes $3 \mathrm{~m}$ by $5 \mathrm{~m}$ rectangular single enclosed perimeter rooms $\left(15 \mathrm{~m}^{2}\right)$. Their orientations were on the south-north axis, with a $40 \%$ window-to-floor ratio in the south façade, which was assumed to be an opening without any shading devices and exterior obstructions. It should be mentioned that in all evaluations, different factors and parameters, such as the $40 \%$ window-to-floor ratio, PMV and PPD were set and evaluated based on the ASHRAE 55: 2009 (Table 2). In the first phase, all case studies were considered to have a $2.6 \mathrm{~m}$ height, which is the minimum acceptable height in the North Cyprus regulations. In this regard, different ventilation scenarios, which are $24 \mathrm{~h}$ air-conditioning, day-time ventilation and night-time ventilation, were evaluated. Then, in order to have a comparison, these processes were repeated for the $3.5 \mathrm{~m}$ height, which is the maximum acceptable height (Tables 3-5).

Table 2. Thermal comfort parameter setting.

\begin{tabular}{cc}
\hline \multicolumn{2}{c}{ Thermal Comfort Parameters Setting } \\
\hline Activity Factor & 1.00 \\
Winter Clothing & $1.00 \mathrm{clo}$ \\
Summer Clothing & $0.50 \mathrm{clo}$ \\
Heating Set-point Temperature & $20.00{ }^{\circ} \mathrm{C}$ \\
Cooling Set-point Temperature & $26.00{ }^{\circ} \mathrm{C}$ \\
Winter Operative Temperature Range & $14-20{ }^{\circ} \mathrm{C}$ \\
Summer Operative Temperature Range & $23-26{ }^{\circ} \mathrm{C}$ \\
Heating Comfort PMV Set-point & $-0.5 /-0.7$ \\
Cooling Comfort PMV Set-point & $0.5 / 0.7$ \\
\hline Indoor Air Quality Parameters Setting \\
\hline RH Humidification Set-point & $10.00 \%$ \\
RH Dehumidification Set-point & $90.00 \%$ \\
Minimum Fresh Air & $2.50 \mathrm{~L} / \mathrm{s}-\mathrm{person}$ \\
$\mathrm{CO}_{2}$ Set-point & $900 \mathrm{ppm}$ \\
Minimum CO ${ }_{2}$ Concentration & $600 \mathrm{ppm}$ \\
\hline
\end{tabular}




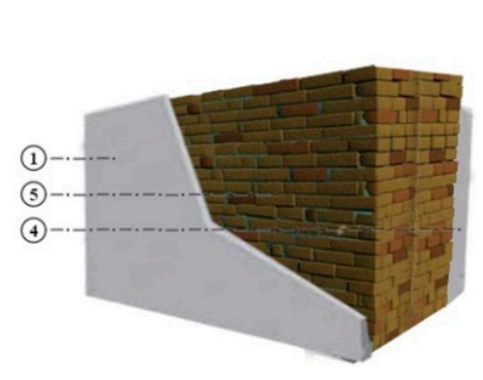

Traditional

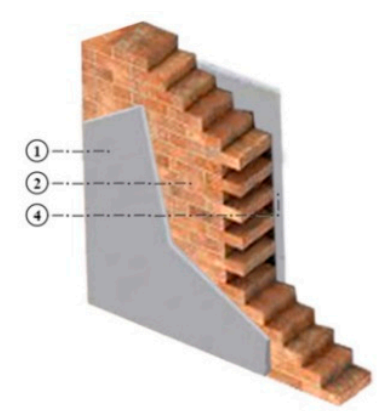

Without Insulation

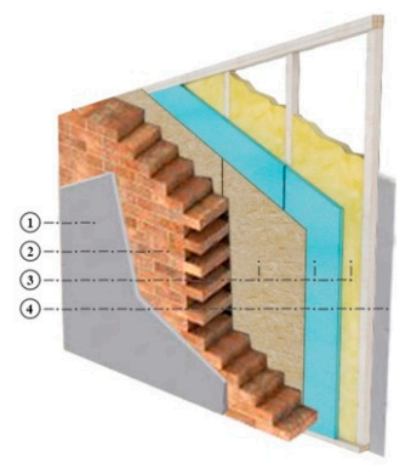

Inner layer Insulated

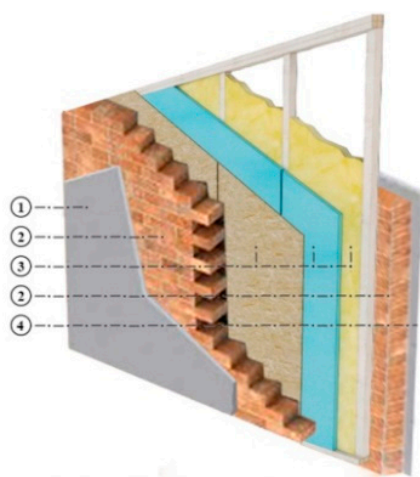

Middle Layer Insulated

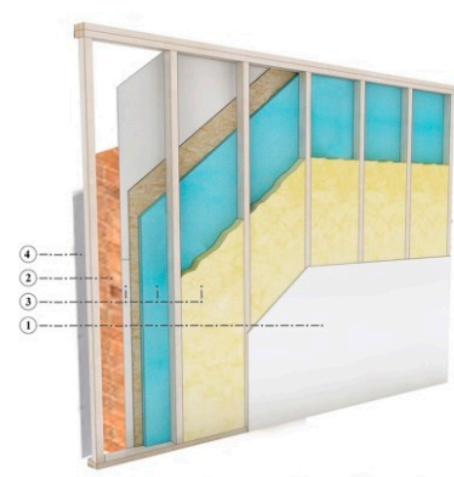

Exterior Layer Insulated

Figure 4. Different types of case studies' schematic wall system details.

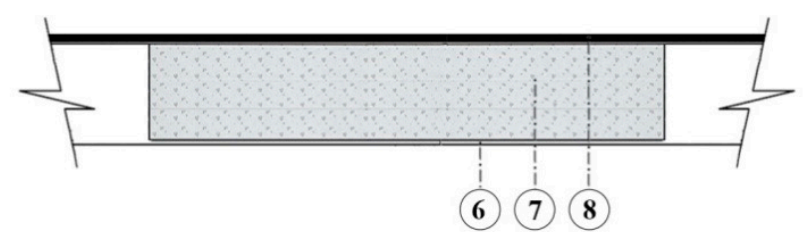

Without Insulation

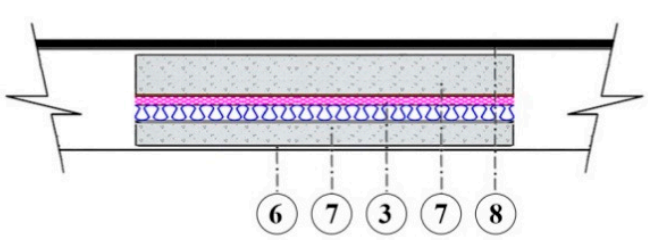

Inner layer Insulated

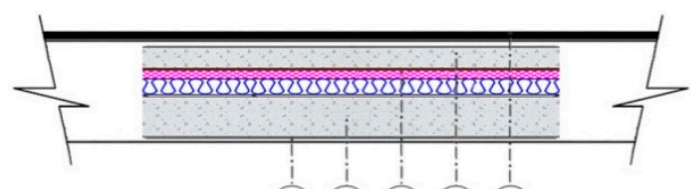

(6) (7) (3) 78

Exterior Layer Insulated

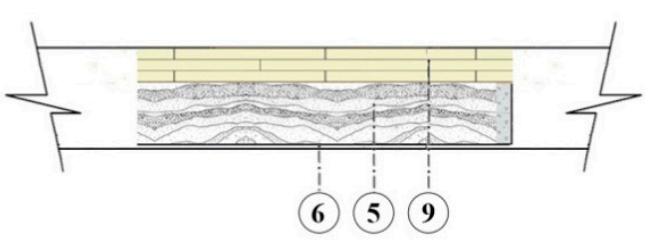

Traditional

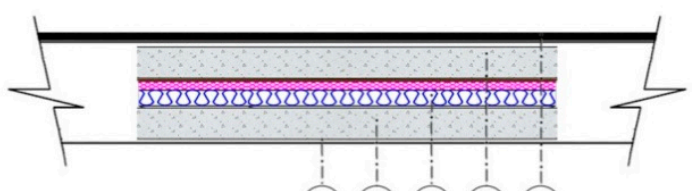

(6) 7 (3) 78

Middle Layer Insulated

Figure 5. Different types of case studies' schematic ceiling system details (thermal properties of labeled construction materials are presented in Table 5). 
Table 3. Different types of case studies' wall materials.

\begin{tabular}{|c|c|c|c|c|}
\hline \multicolumn{5}{|c|}{ Wall Structure } \\
\hline Traditional & $\begin{array}{l}\text { Without } \\
\text { Insulation }\end{array}$ & $\begin{array}{l}\text { Inner Layer } \\
\text { Insulated }\end{array}$ & $\begin{array}{l}\text { Middle Layer } \\
\text { Insulated }\end{array}$ & $\begin{array}{l}\text { Outer Layer } \\
\text { Insulated }\end{array}$ \\
\hline \multirow{2}{*}{$\begin{array}{l}1.5 \mathrm{~cm} \text { Gypsum } \\
\text { Plastering }\end{array}$} & \multirow{2}{*}{$\begin{array}{l}1.5 \mathrm{~cm} \text { Gypsum } \\
\text { Plastering }\end{array}$} & \multirow{2}{*}{$\begin{array}{c}1.5 \mathrm{~cm} \text { Gypsum } \\
\text { Plastering }\end{array}$} & $\begin{array}{l}1.5 \mathrm{~cm} \text { Gypsum } \\
\text { Plastering }\end{array}$ & $\begin{array}{l}1.5 \mathrm{~cm} \text { Gypsum } \\
\text { Plastering }\end{array}$ \\
\hline & & & $\begin{array}{c}12.5 \mathrm{~cm} \text { Brickwork, } \\
\text { Outer Leaf }\end{array}$ & $\begin{array}{c}25 \mathrm{~cm} \text { Brickwork, } \\
\text { Outer Leaf }\end{array}$ \\
\hline \multirow{5}{*}{$\begin{array}{l}40 \mathrm{~cm} \text { Adobe } \\
\text { (Soil, Earth, } \\
\text { Common) }\end{array}$} & \multirow{5}{*}{$\begin{array}{l}30 \mathrm{~cm} \text { Brickwork, } \\
\text { Outer Leaf }\end{array}$} & \multicolumn{3}{|c|}{$\begin{array}{l}5 \mathrm{~cm} \text { depth metal framing, R-13 Insulation, Expanded } \\
\text { polystyrene, molded beads (Effective Insulation/Framing layers } \\
\text { added to Above-Grade Mass walls \& Below-Grade walls) }\end{array}$} \\
\hline & & \multicolumn{3}{|c|}{ Framing and cavity insulation } \\
\hline & & \multicolumn{3}{|c|}{ Rigid foam insulation } \\
\hline & & \multicolumn{3}{|c|}{ Wood structural sheathing } \\
\hline & & \multicolumn{3}{|c|}{ Water Resistant Barrier } \\
\hline \multirow{2}{*}{$\begin{array}{c}1 \mathrm{~cm} \text { Plaster } \\
\text { (Dense) }\end{array}$} & \multirow{2}{*}{$\begin{array}{c}1 \mathrm{~cm} \text { Plaster } \\
\text { (Dense) }\end{array}$} & $\begin{array}{l}25 \mathrm{~cm} \text { Brickwork, } \\
\text { Outer Leaf }\end{array}$ & $\begin{array}{l}12.5 \mathrm{~cm} \text { Brickwork, } \\
\text { Outer Leaf }\end{array}$ & \multirow{2}{*}{$\begin{array}{c}1 \mathrm{~cm} \text { Plaster } \\
\text { (Dense) }\end{array}$} \\
\hline & & $\begin{array}{c}1 \mathrm{~cm} \text { Plaster } \\
\text { (Dense) }\end{array}$ & $\begin{array}{c}1 \mathrm{~cm} \text { Plaster } \\
\text { (Dense) }\end{array}$ & \\
\hline
\end{tabular}

Table 4. Different types of case studies' ceiling materials.

\begin{tabular}{|c|c|c|c|c|}
\hline \multicolumn{5}{|c|}{ Ceiling Structure } \\
\hline Traditional & $\begin{array}{l}\text { Without } \\
\text { Insulation }\end{array}$ & $\begin{array}{l}\text { Inner Layer } \\
\text { Insulated }\end{array}$ & $\begin{array}{l}\text { Middle Layer } \\
\text { Insulated }\end{array}$ & $\begin{array}{l}\text { Outer Layer } \\
\text { Insulated }\end{array}$ \\
\hline $\begin{array}{l}1.5 \mathrm{~cm} \text { Plaster } \\
\text { (Lightweight) }\end{array}$ & $\begin{array}{l}1.5 \mathrm{~cm} \text { Plaster } \\
\text { (Lightweight) }\end{array}$ & $\begin{array}{l}1.5 \mathrm{~cm} \text { Plaster } \\
\text { (Lightweight) }\end{array}$ & $\begin{array}{l}1.5 \mathrm{~cm} \text { Plaster } \\
\text { (Lightweight) }\end{array}$ & $\begin{array}{l}1.5 \mathrm{~cm} \text { Plaster } \\
\text { (Lightweight) }\end{array}$ \\
\hline \multirow{2}{*}{$\begin{array}{l}15 \mathrm{~cm} \text { Adobe (Soil, } \\
\text { Earth, Common) }\end{array}$} & \multirow{3}{*}{$15 \mathrm{~cm}$ Concrete } & $5 \mathrm{~cm}$ Concrete & $7.5 \mathrm{~cm}$ Concrete & $10 \mathrm{~cm}$ Concrete \\
\hline & & \multicolumn{3}{|c|}{$\begin{array}{l}5 \mathrm{~cm} \text { depth metal framing, R-13 Insulation, Expanded } \\
\text { polystyrene, molded bead }\end{array}$} \\
\hline $5 \mathrm{~cm}$ Clay Tile & & $10 \mathrm{~cm}$ Concrete & $7.5 \mathrm{~cm}$ Concrete & $5 \mathrm{~cm}$ Concrete \\
\hline $3.5 \mathrm{~cm}$ Asphalt & $3.5 \mathrm{~cm}$ Asphalt & $3.5 \mathrm{~cm}$ Asphalt & $3.5 \mathrm{~cm}$ Asphalt & $3.5 \mathrm{~cm}$ Asphalt \\
\hline
\end{tabular}

Table 5. Thermal properties of construction materials.

\begin{tabular}{lccccccc}
\hline Materials & $\begin{array}{c}\text { Conductivity } \\
(\mathbf{W} / \mathbf{m}-\mathbf{K})\end{array}$ & $\begin{array}{c}\text { Specific } \\
\text { Heat } \\
(\mathbf{J} / \mathbf{k g}-\mathbf{K})\end{array}$ & $\begin{array}{c}\text { Density } \\
\left(\mathbf{k g} / \mathbf{m}^{3}\right)\end{array}$ & $\begin{array}{c}\text { Thermal } \\
\text { Absorptance } \\
(\text { Emissivity) }\end{array}$ & $\begin{array}{c}\text { Embodied } \\
\text { Carbon } \\
(\mathbf{k g C O} / \mathbf{k g})\end{array}$ & $\begin{array}{c}\text { Thermal } \\
\text { Diffusivity } \\
\left(\mathbf{m}^{2} / \mathbf{s}\right)\end{array}$ \\
\hline $\mathbf{1}$ & Gypsum Plastering & 0.400 & 1000 & 1000 & 0.900 & 0.38 & $4 \times 10^{-7}$ \\
\hline $\mathbf{2}$ & Brick & 0.840 & 800 & 1700 & 0.900 & 0.22 & $6.1 \times 10^{-7}$ \\
\hline $\mathbf{3}$ & Insulation & 0.355 & 1470 & 10.00 & 0.900 & $-\cdots$ & $2.4 \times 10^{-7}$ \\
\hline $\mathbf{4}$ & Plaster (Dense) & 0.500 & 1000 & 1300 & 0.900 & 0.12 & $3.8 \times 10^{-7}$ \\
\hline $\mathbf{5}$ & $\begin{array}{c}\text { Adobe } \\
\text { (Soil, Earth, Common) }\end{array}$ & 1.280 & 880 & 1460 & 0.900 & 0.02 & $9.9 \times 10^{-7}$ \\
\hline $\mathbf{6}$ & Plaster (Lightweight) & 0.160 & 1000 & 600 & 0.900 & 0.12 & $2.6 \times 10^{-7}$ \\
\hline $\mathbf{7}$ & Concretes & 2.270 & 837.36 & 2321.40 & 0.900 & $-\cdots$ & $1.2 \times 10^{-6}$ \\
\hline $\mathbf{8}$ & Asphalt & 0.700 & 1000 & 2100 & 0.900 & 0.05 & $3.3 \times 10^{-7}$ \\
\hline $\mathbf{9}$ & Clay Tile & 1.000 & 800 & 2000 & 0.900 & 0.46 & $6.2 \times 10^{-7}$ \\
\hline
\end{tabular}


Although vernacular architecture was based on the free-run period, currently, with the improvement of residents' lifestyles, it seems almost impossible to achieve thermal comfort without mechanical systems. Therefore, a mixed-use mode is proposed for this model, based on the ASHRAE 55: 2009; if the PMV ranged between -1 and +1 , this free-run period can be accepted as the thermal comfort period. Therefore, in these times, mechanical ventilation can be eliminated. It should be mentioned that the evaluation method is based on the hourly results. From these hourly results, the total percentage of acceptable hours that are in the PMV range have been calculated for each day.

As was presented, recent studies have mainly tried to investigate the energy efficiency in buildings by calculating energy consumption and evaluating building performance accordingly, as a kind of single variable analysis. However, in this study, the evaluation process was done based on the sense of thermal comfort satisfaction in two different stages, which were with an air conditioning system and without it, which is called free-running. Then, these two were combined as a mixed mode. Afterwards, in order to see the effectiveness of this method, it was applied in buildings with different construction techniques to provide a comparison between contemporary and vernacular architecture with different ventilation scenarios, such as day-time ventilated, night-time ventilated and $24 \mathrm{~h}$ mechanically air conditioned. Therefore, this study tries to investigate the model to present applicable free-run periods for the mixed-mode at certain periods of a year, rather than simply suggesting that building users open windows at different times of each day to benefit from natural ventilation as a mixed mode. In other words, this study tries to investigate a model to redefine the concept of mixed mode.

The main concept of mixed-mode (MM) or so-called hybrid ventilation is to provide satisfactory indoor environments by alternating between and combining natural and mechanical systems. A preference for free-running or a naturally ventilated mode create the appropriate air quality and thermal comfort for buildings, while keeping down costs and reducing the carbon footprint. Meanwhile, these buildings will revert to mechanical systems for heating, cooling, ventilation and air conditioning (HVAC) whenever external conditions make the natural ventilation option untenable for occupants [96]. Previous studies show the disparities between steady state and adaptive comfort models in air conditioned and naturally ventilated buildings [34]. In this regard, ASHRAE's Standard 55 (2010) classifies mixed-mode buildings as air-conditioned ones and, as such, increases the limits of the operation of these buildings to the more acceptable PMV-PPD range of indoor thermal conditions $(-1<$ PMV $<+1)[35]$.

However, authors believed that applying the mentioned scenario for $24 \mathrm{~h}$ of the day may lead to imprecise results. Therefore, results were taken for day-time ventilation and night-time ventilation separately, and then compared with $24 \mathrm{~h}$ results. This is because in summer, for example, we may reach a comfort zone at night-time, but not at day-time, and vice versa in winter, which will be really meaningful in the case of office buildings.

The next step is evaluation of mechanical system (HVAC) performance. In this regard, again the three described scenarios-day-time, night-time and $24 \mathrm{~h}$ operation-based evaluation-were tested. Here, in order to achieve optimum energy consumption, it was attempted to run the simulation program for the advised acceptable range of thermal comfortable temperatures in ASHRAE 55: 2009 separately. In other words, the acceptable range of comfort hours must be more than 80-90\% (adoptive-with HVAC system) for mechanical or mixed-mode systems. Then, the minimum temperature that is able to create a comfort zone in winter, and the maximum temperature in summer, were selected to perform energy consumption calculations. This aimed to create an optimum status in which both thermal comfort satisfaction and minimum energy usage were achieved.

Based on the above data, the mixed-mode system was developed. In this scenario, the times that national ventilation can create a comfort zone are presented as free-run periods without energy consumption and, for the rest of the year, air-conditioned systems create the thermal comfort zone. Since displaying all the results of the different scenarios tested here is outside of the scope of this paper, only one chart is presented as a sample (Figure 6), and the results are presented below. 


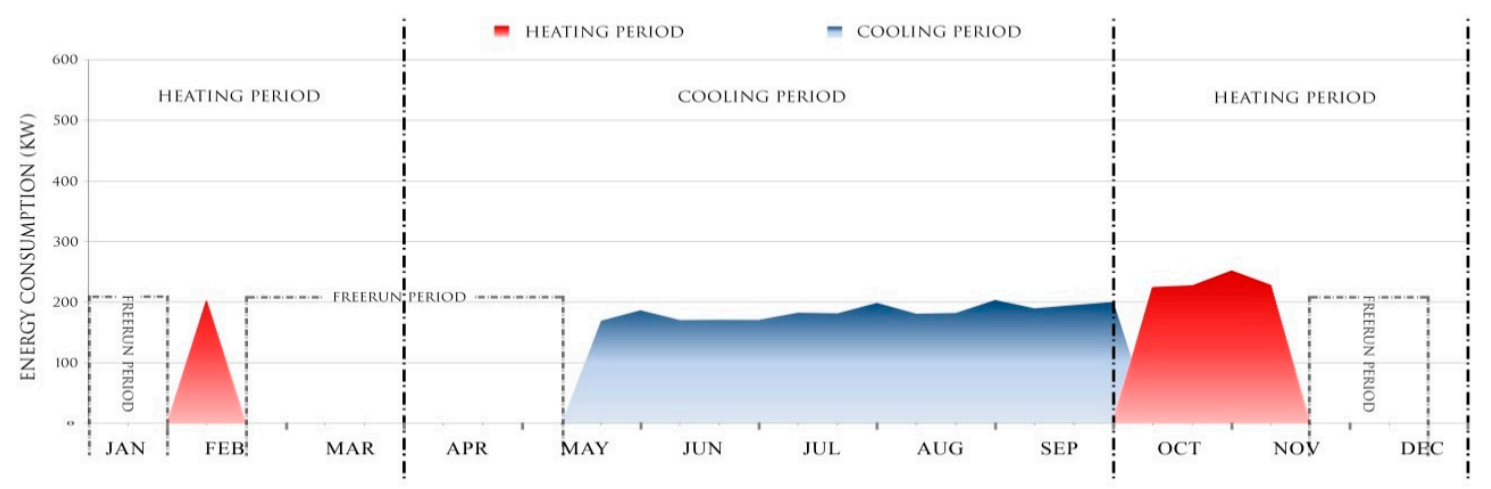

Figure 6. Yearly energy consumption of $2.6 \mathrm{~m}$ height, day-time ventilated inner layer insulated model.

From these results, it can be seen that, as was predicted, in the hot summers of Cyprus, it is almost impossible to reach $100 \%$ thermal comfort with natural ventilation. However, it can be seen that there is a potential for benefiting from the free-run periods in heating times, such as in November, December and even January. This period can be increased by improving the material properties and/or increasing thermal diffusivity or conductivity. For instance, as was predicted, the longest free-run periods are derived from the traditional model, and this period grows around $7 \%$ by increasing the model height. This issue is highlighted in summer night-times. On the other hand, in contrast with the vernacular case study, increasing the building height does not have a significant effect on increasing free-run periods in contemporary cases. However, changing the position of insulation layers shows that in case of day-time ventilated buildings, insulating a building from the exterior layers increases the free-run periods, especially with height increment. For other scenarios, a middle layer of insulation is suggested. However, it should be mentioned that it does not have a significant effect on total free-run periods. The next charts (Figure 7) present the sum of the hours in a year, in which each of the cases can benefit from free-running in summer, winter and the whole year. These charts are used in order to understand the potential effectiveness of each case for saving energy in heating and cooling periods (Figures 7 and 8).

To have a better comparison among these free-run periods in different seasons, all the previous charts (Figure 7) are combined in Figure 8. Furthermore, it is illustrated that in the case of vernacular architecture, increasing the floor-to-ceiling height has positive effects in the form of increasing free-run periods $(6 \%)$. This was an effective factor in the period in which there were no mechanical systems. However, in order to evaluate the effectiveness of these buildings, the same type of HVAC system was added to the traditional models as well. As a result, the amount of energy consumption was reduced by increasing the height. The reduction is maximized in case of the night-time ventilated model in the summer time, which shows a $21 \%$ reduction in total energy consumption. However, this rule cannot be applied for the other cases. In models that are constructed with contemporary materials, increasing the height leads to an increase in total energy consumption of between 6 and 9\% in mixed-mode scenarios. Therefore, although increasing building height may increase the free-run periods, in contemporary buildings, it increases the total energy usage of the buildings in mixed mode. On the other hand, if these types are compared with the $24 \mathrm{~h}$ air-conditioned buildings, they show up to $64 \%$ energy savings in similar cases (Figures 9 and 10).

Figures 9 and 10 display building energy consumption in the mixed mode. In other words, after calculating the free-run periods, these times are considered as zero energy consumers for heating and cooling. Then, the building energy performance for the rest of the year is calculated. This has been done to present the effect of free-run periods on total energy performance of the building. Although increasing building height facilitates reaching a thermal comfort zone in free-run periods, it increases the total energy consumption at other times. However, this energy usage can still be controlled and optimized by such considerations as insulation material placement. 

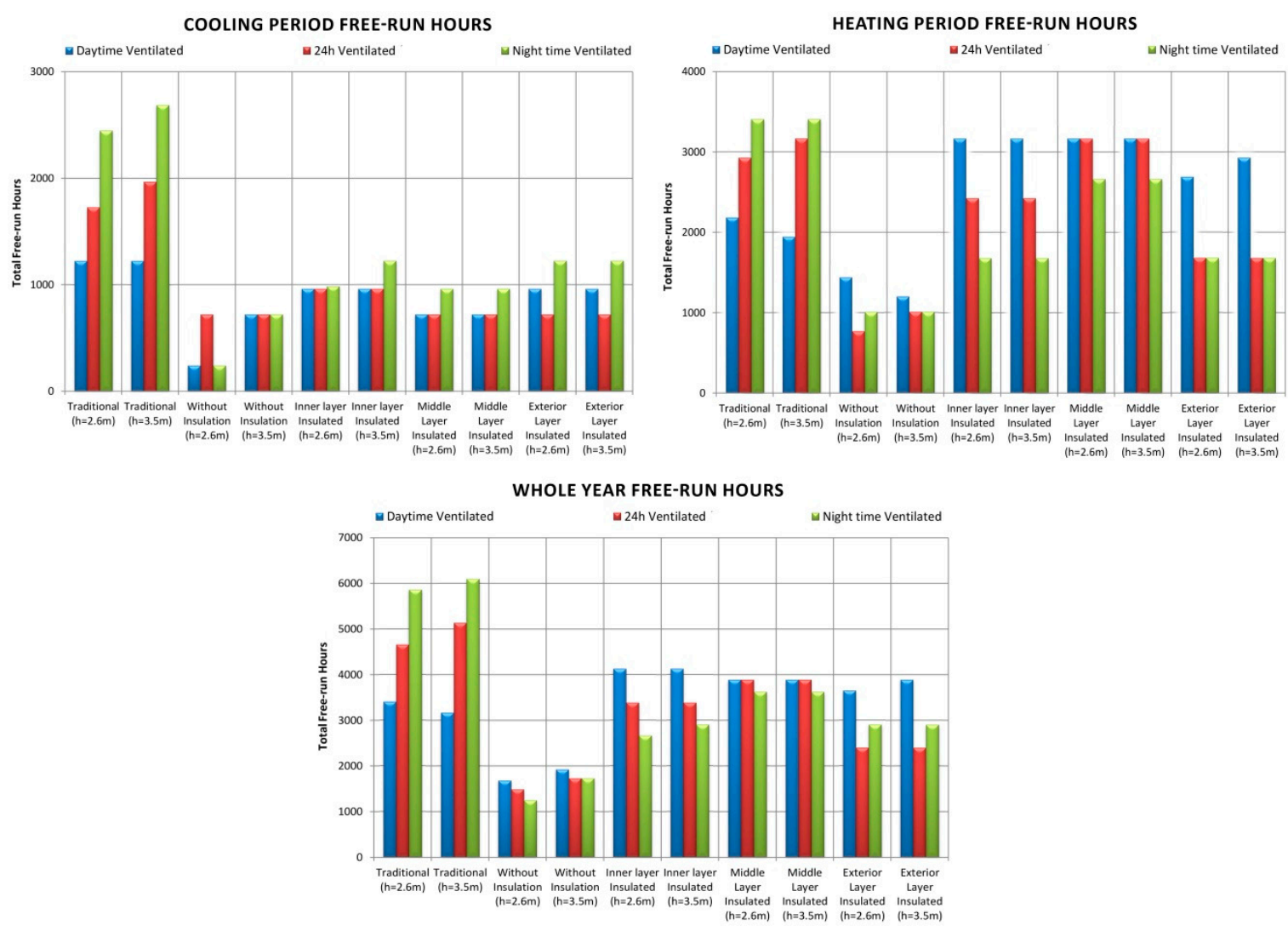

Figure 7. Building free-run hours in different scenarios.

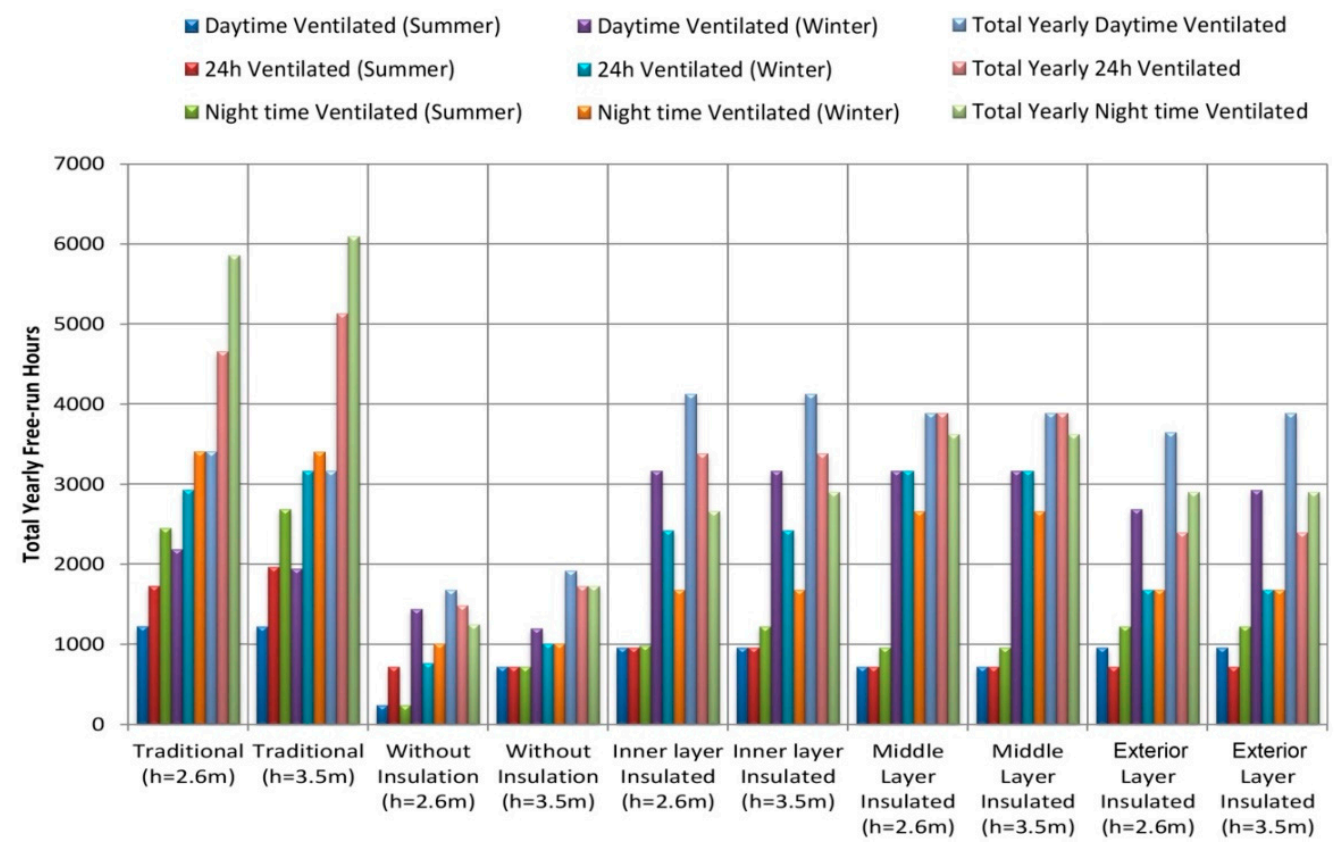

Figure 8. Building total free-run hours in different scenarios. 

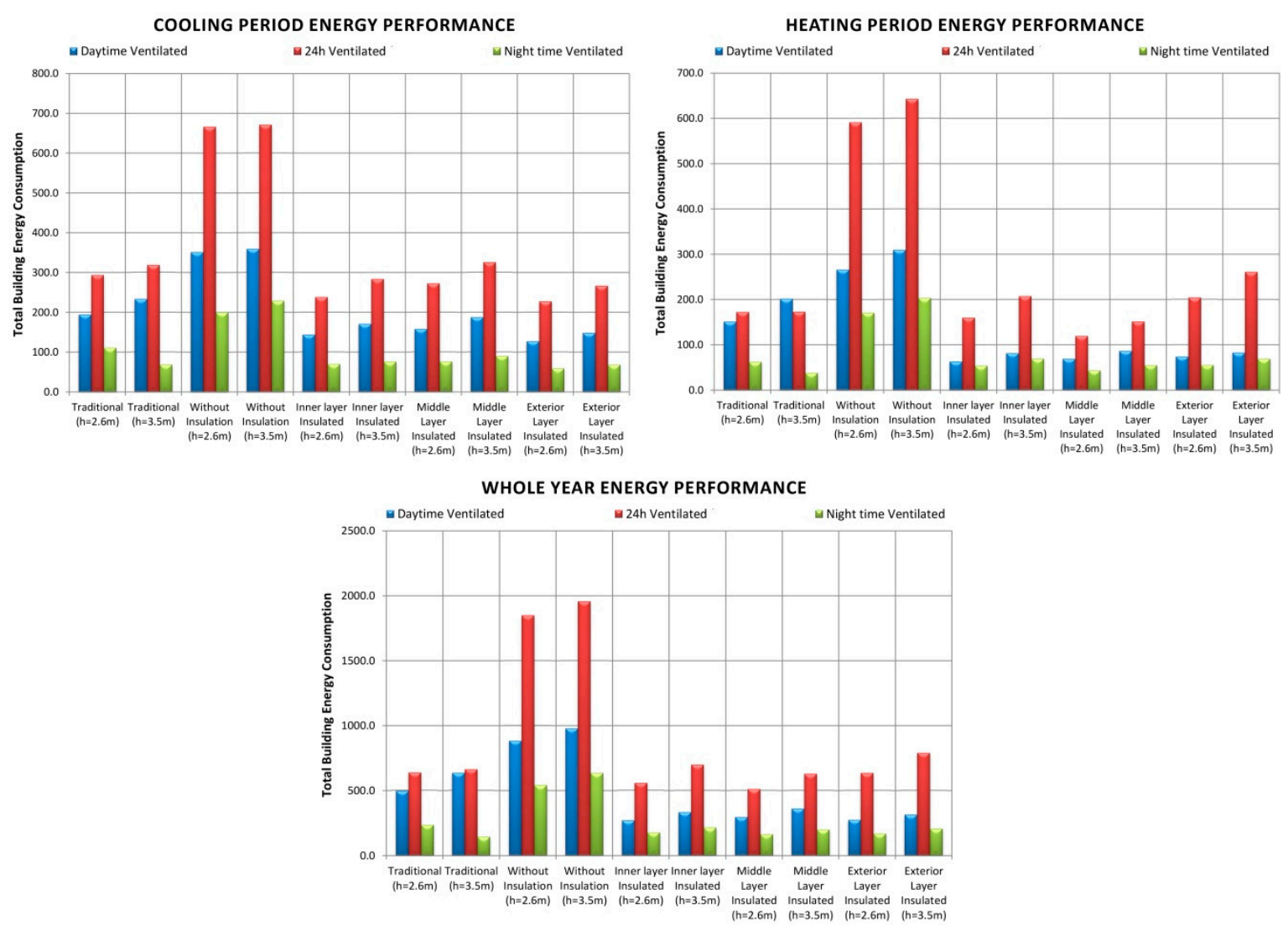

Figure 9. Building energy consumption in different scenarios.

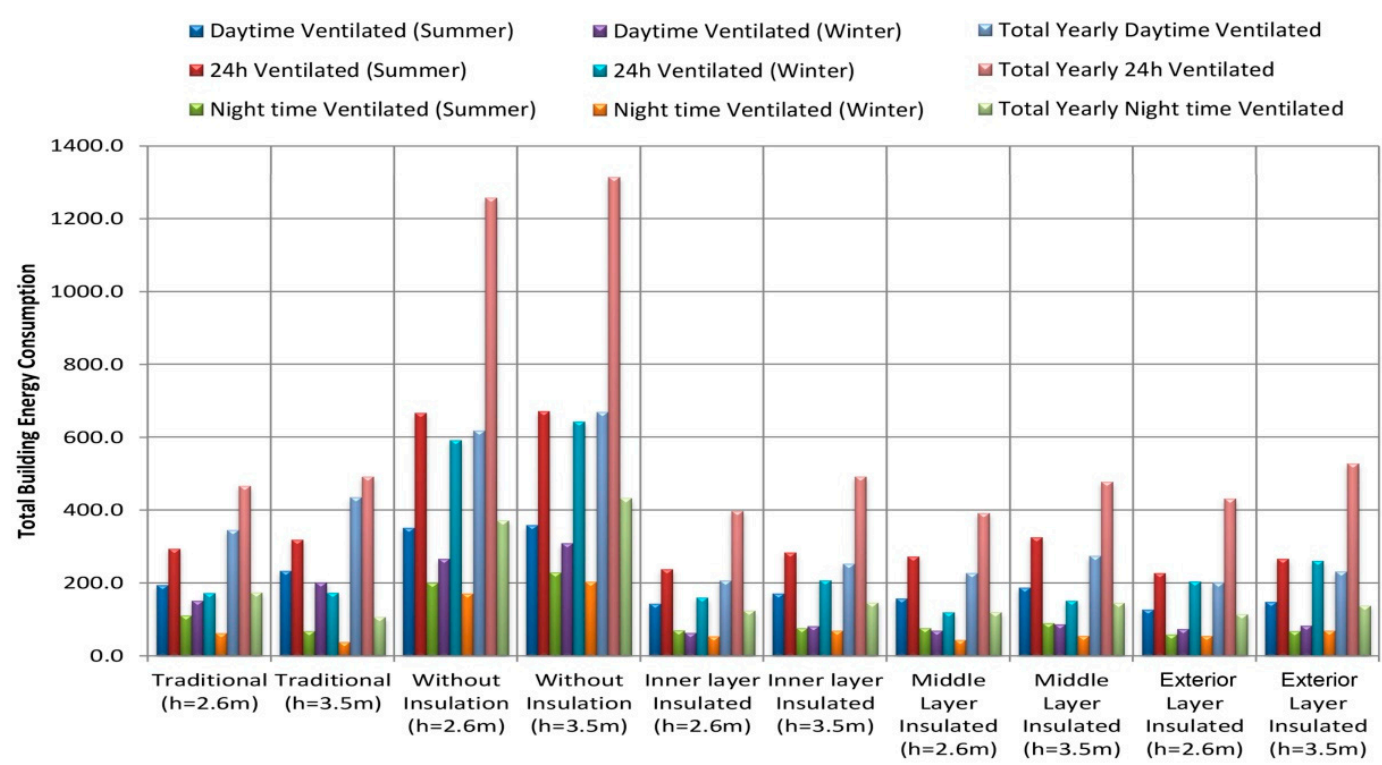

Figure 10. Building energy consumption in different scenarios.

In this regard, the model without any insulation materials with a $2.6 \mathrm{~m}$ height, which is a more common type of contemporary construction technique in Northern Cyprus, is considered to be a base point for comparison. Then the following results (percentages) are concluded from the comparison between the base model and different case studies in different scenarios. These results are presented graphically in Figure 11. To sum up, according to materials' condensation, it is demonstrated that in hot and humid climates, during hot summers the best placement of the insulation layer is in the exterior layer. In this way, energy usage can be reduced by $64-71 \%$. Furthermore, if the insulation material is 
located in the middle of the wall, it has a better performance in winters, which leads to energy saving of $74-80 \%$ in different functional types of buildings. Additionally, insulating the inner layer of the walls reduced energy usage of the day-time ventilated buildings by $78 \%$ and can be proposed for office buildings, which are only used in day-times. Finally, due to the $67 \%$ saving for the whole year, both inner and exterior layer insulation can be recommended for day-time ventilated buildings. For $24 \mathrm{~h}$ ventilated buildings such as residential buildings, insulation in the middle layer is suggested $(69 \%$ reduction). Furthermore, this saving can be $71 \%$ in the case of the $3.5 \mathrm{~m}$ height vernacular case study in night-time ventilated mode, which shows the effectiveness of traditional buildings considerations (Figure 11).

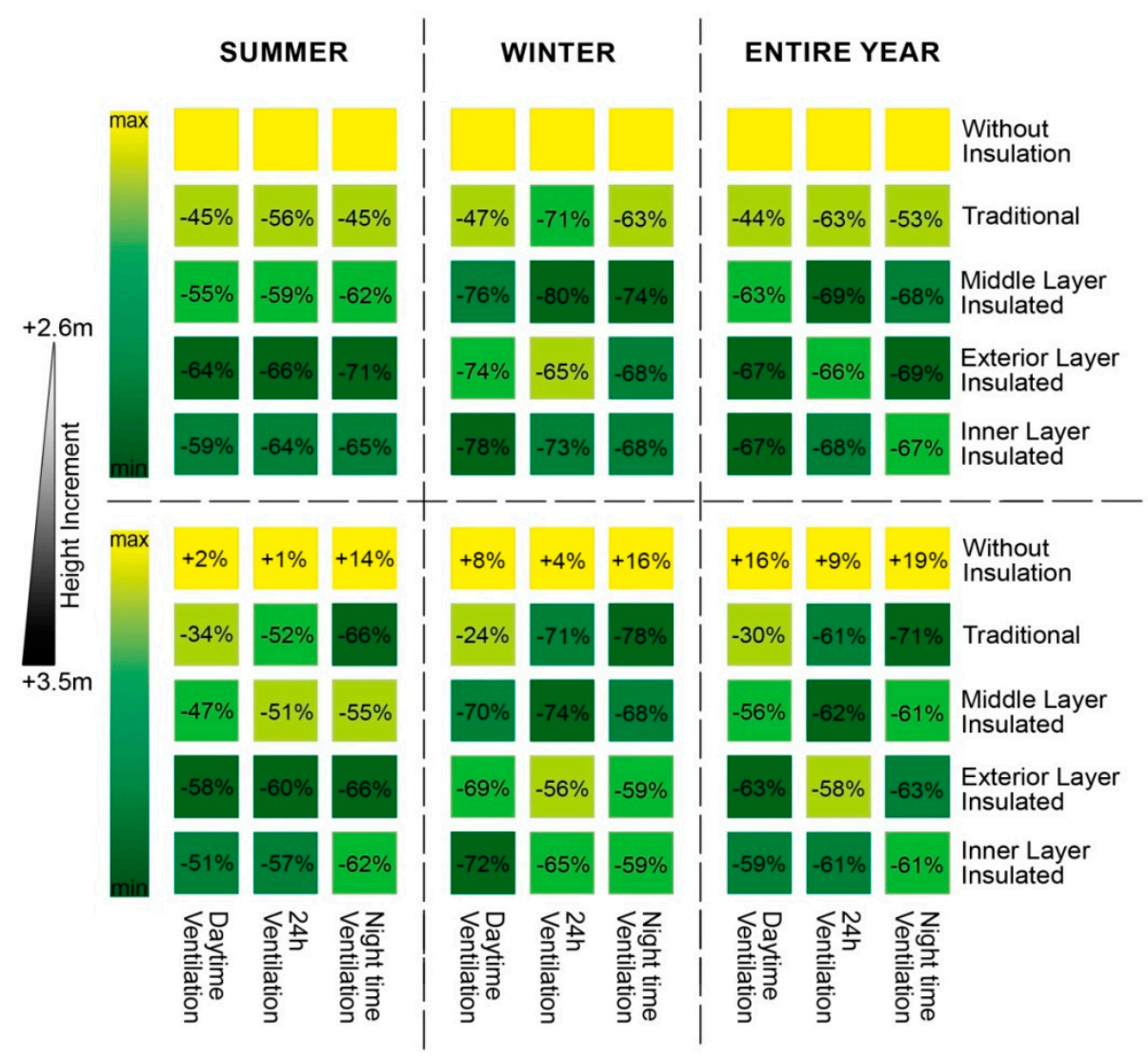

Figure 11. Energy consumption in different scenarios in comparison to the $2.6 \mathrm{~m}$ traditional model as the origin of evaluation.

\section{Conclusions}

The main aim of designing buildings is to create a comfortable environment for residents. Currently, there is an argument that by using the passive design principals of traditional architecture, more thermal comfort can be achieved in buildings. In vernacular architecture, it was not possible to create a $100 \%$ thermal comfort zone, so the attempt was made instead to reduce the amount of dissatisfaction. Therefore, architects tried to use thick walls, high ceilings and big openings to gain more benefit from natural environments in hot summers, with spaces heated by fire in winters. However, in recent times, by using mechanical ventilation systems, achieving comfort zones is easier. Based on the results, although increasing height leads to increasing the free-run periods in traditional buildings and at the same time increasing the sense of thermal comfort, it does not affect insulated contemporary buildings. Increasing height can only increase the free-run times of uninsulated buildings. However, this increment leads to an increase in total building energy performance in all cases.

Therefore, except for a period from December to March and in the middle of May, the mechanical systems might work to create a comfort zone. Furthermore, this issue can be more beneficial in 
summer night-times. However, in this case, energy performance should be considered. Thus, this research proposed and analyzed different scenarios to evaluate this performance. In other words, it is demonstrated that vernacular architecture construction techniques were successful in their context and time. In the case of considering buildings that are totally naturally ventilated without using air-conditioning systems, they may be applicable. However, as peoples' current lifestyles and expectations of their thermally comfortable environments have increased, it seems that it is not a proper solution to apply vernacular architecture constructional techniques to contemporary buildings.

To summarize, in contrast with vernacular buildings, increasing the building height does not have a significant effect on increasing free-run periods in insulated contemporary constructions. However, changing the placement of insulation layers, illustrated by the case of daytime ventilated buildings such as offices, and insulating buildings from exterior layers, increases the free-run periods, especially with height increment in mixed mode. For the remaining scenarios, middle-layer insulation is suggested. On the other hand, this height increment leads to an increase of total energy consumption between 6 and $9 \%$ in mixed-mode scenarios. However, these scenarios nonetheless save up to two times more energy in comparison with the $24 \mathrm{~h}$ air-conditioned buildings.

Although increasing building height facilitates reaching a thermal comfort zone in free-run periods, it increases the total energy consumption at other times. However, this energy usage can nonetheless be controlled and optimized by such considerations as insulation material placement. In this regard, in hot summers, the best placement of the insulation layer is in exterior layers. Furthermore, if the insulation material is installed in the middle of the wall, it has a better performance in winter in different functional types of buildings. Insulating the inner layer of walls provides the best performance for day-time ventilated buildings and can be proposed for office and educational buildings, which are only used in day-times. Finally, for the whole year, both inner and exterior layer insulation can be recommended for day-time ventilated buildings. For $24 \mathrm{~h}$ ventilated buildings such as residential buildings, insulation in the middle layer is suggested. Therefore, it can be claimed that at the present time, by changing building entities, it is not necessary to blindly repeat previous work. However, architects should design for the present with an awareness of the past. In this way, by considering new construction techniques and insulation materials, the approach to facing traditional problems may change. Currently, by developing technology, a large number of simulation programs have been produced in order to analyze building performance. However, the creation of additional modules to identify free-running periods should be a further development.

Author Contributions: Conceptualization, P.L. and P.H.; methodology, P.L.; software, P.L.; validation, P.L. and P.H.; formal analysis, P.L.; investigation, P.L.; resources, P.L.; writing—original draft preparation, P.L.; writing一review and editing, P.L. and P.H.; supervision, P.H.; project administration, P.H.; funding acquisition, P.L. and P.H.

Funding: This research received no external funding.

Conflicts of Interest: The authors declare no conflict of interest.

\section{References}

1. Ferrari, S.; Zanotto, V. Adaptive comfort: Analysis and application of the main indices. Build. Environ. 2012, 49, 25-32. [CrossRef]

2. CEN/EN15251. Indoor Environmental Input Parameters for Design and Assessment of Buildings: Addressing Indoor Air Quality, Thermal Environment, Lighting and Acoustics; Comite Europeen de Normalisation: Brussels, Belgium, 2007.

3. Ozay, N. A comparative study of climatically responsive house design at various periods of Northern Cyprus architecture. Build. Environ. 2005, 40, 841-852. [CrossRef]

4. Nicol, J.F. Adaptive thermal comfort standards in the hot and humid tropics. Energy Build. 2004, 36, 628-637. [CrossRef]

5. Nicol, J.; Humphreys, M. Adaptive thermal comfort and sustainable thermal standards for buildings. Energy Build. 2002, 34, 563-572. [CrossRef] 
6. Kumar, S.; Singh, M.K.; Kukreja, R.; Chaurasiya, S.K.; Gupta, V.K. Comparative study of thermal comfort and adaptive actions for modern and traditional multi-storey naturally ventilated hostel buildings during monsoon season in India. J. Build. Eng. 2019, 23, 90-106. [CrossRef]

7. Raja, I.A.; Nicol, J.F.; McCartney, K.J.; Humphreys, M.A. Thermal comfort: Use of controls in naturally ventilated buildings. Energy Build. 2001, 33, 235-244. [CrossRef]

8. Kenisarin, M.; Mahkamov, K. Passive thermal control in residential buildings using phase change materials. Renew. Sustain. Energy Rev. 2016, 55, 371-398. [CrossRef]

9. Parsons, K. Thermal comfort in buildings. In Materials for Energy Efficiency and Thermal Comfort in Buildings; Woodhead Publishing: Cambridge, UK, 2010; pp. 127-147.

10. Kaviany, M. Heat Transfer Physics, 2nd ed.; Cambridge University Press: Cambridge, UK, 2014.

11. Guimarães, R.P.; Carvalho, M.C.R.; Santos, F.A. The Influence of Ceiling Height in Thermal Comfort of Buildings: A Case Study in Belo Horizonte, Brazil. Int. J. Hous. Sci. 2013, 37, 75-85.

12. Pulhan, H.; Numan, I. The Traditional Urban House in Cyprus as Material Expression of Cultural Transformation. J. Des. Hist. 2006, 19, 105-119. [CrossRef]

13. Lotfabadi, P. Optimization Method of Transparency Ratio for Building Envelope in Terms of Thermal and Visual Comfort. Ph.D. Thesis, Eastern Mediterranean University, Famagusta, Northern Cyprus, 2019. Unpublished work.

14. Huizenga, C.; Abbaszadeh, S.; Zagreus, L.; Arens, E.A. Air quality and thermal comfort in office buildings: Results of a large indoor environmental quality survey. In Proceedings of the Healthy Buildings, Lisbon, Portugal, 4-8 June 2006; pp. 393-397.

15. Wägner, A.; Gossauer, E.; Moosmann, C.; Gropp, T.; Leonhart, R. Thermal comfort and workplace occupant satisfaction-Results of field studies in German low energy office buildings. Energy Build. 2007, 39, 758-769. [CrossRef]

16. Aboulnaga, M.; Abdrabboh, S. Improving night ventilation into low-rise buildings in hot-arid climates exploring a combined wall-roof solar chimney. Renew. Energy 2000, 19, 47-54. [CrossRef]

17. Ghiaus, C. Free-running building temperature and HVAC climatic suitability. Energy Build. 2003, 35, 405-411. [CrossRef]

18. Mahlia, T.; Saidur, R.; Memon, L.; Zulkifli, N.; Masjuki, H. A review on fuel economy standard for motor vehicles with the implementation possibilities in Malaysia. Renew. Sustain. Energy Rev. 2010, 14, 3092-3099. [CrossRef]

19. Lotfabadi, P. The impact of city spaces and identity in the residents' behavior. Humanit. Soc. Sci. Rev. 2013, 3, 589-601.

20. Höppe, P.; Martinac, I. Indoor climate and air quality. Review of current and future topics in the field of ISB study group 10. Int. J. Biometeorol. 1998, 42, 1-7.

21. Gupta, V. Thermal efficiency of building clusters: An index for nonair-conditioned buildings in hot climates. In Energy and Urban Built Form; Butterworth-Heinemann: Oxford, UK, 1987.

22. Lotfabadi, P.; Alibaba, H.Z.; Arfaei, A. Sustainability; as a combination of parametric patterns and bionic strategies. Renew. Sustain. Energy Rev. 2016, 57, 1337-1346. [CrossRef]

23. Fanger, P.O. Human requirements in future air-conditioned environments. Int. J. Refrig. 2001, $24,148-153$. [CrossRef]

24. Kaynakli, O.; Kilic, M. An investigation of thermal comfort inside an automobile during the heating period. Appl. Ergon. 2005, 36, 301-312. [CrossRef]

25. Ozcelik, G.; Becerik-Gerber, B.; Chugh, R. Understanding human-building interactions under multimodal discomfort. Build. Environ. 2019, 151, 280-290. [CrossRef]

26. Tahti, E. Industrial Ventilation Design Guidebook, 1st ed.; Academic Press: San Diego, CA, USA, 2001; pp. $355-413$.

27. Cilik, C.F.; Durmus, K. Energy production, consumption, policies and recent developments in Turkey. Renew. Sustain. Energy Rev. 2007, 14, 1172-1186.

28. Ghobadian, V. Analyzing Iran's Traditional Structures from a Cliamtes Perspective; Tehran Univerdity Press: Tehran, Iran, 1996.

29. Lotfabadi, P. Analyzing passive solar strategies in the case of high-rise building. Renew. Sustain. Energy Rev. 2015, 52, 1340-1353. [CrossRef]

30. Lotfabadi, P. Solar considerations in high-rise buildings. Energy Build. 2015, 89, 183-195. [CrossRef] 
31. Wright, G.R.H. Ancient Buildings in Cyprus; E. J. Brill: Leiden, The Netherlands, 1992.

32. Lotfabadi, P. High-rise buildings and environmental factors. Renew. Sustain. Energy Rev. 2014, 38, $285-295$. [CrossRef]

33. ANSI/ASHRAE Standard 55. Thermal Environmental Conditions for Human Occupancy; American Society of Heating, Refrigerating and Air-Conditioning Engineers, Inc.: Atlanta, GA, USA, 2004.

34. Humphreys, M.A.; Nicol, F. Understanding the adaptive approach to thermal comfort. ASHRAE Trans. 1998, 104, 991-1004.

35. ANSI/ASHRAE Standard 55. Thermal Environmental Conditions for Human Occupancy; American Society of Heating, Refrigerating and Air-Conditioning Engineers, Inc.: Atlanta, GA, USA, 2010.

36. Luma Sense Technologies. Available online: http://www.lumasenseinc.com/preview.php?tpl=content\& $\mathrm{mID}=3621 \& \mathrm{cID}=0 \& \operatorname{lng}=$ de-deu (accessed on 8 May 2016).

37. Olgyay, V. Design with Climate, Bioclimatic Approach to Architectural Regionalism; Princeton University Press: Princeton, NJ, USA, 2015.

38. Katafygiotou, M.C.; Serghides, D.K. Bioclimatic chart analysis in three climate zones in Cyprus. Indoor Built Environ. 2015, 24, 746-760. [CrossRef]

39. Serghides, D.K. Integrated Design for the Zero Energy House and the Human Factor. In Proceedings of the PLEA 2008 Towards Zero Energy Building, Dublin, Ireland, 23 October 2008; pp. 22-24.

40. Al-Azri, N.; Zurigat, Y.; Al-Rawahi, N. Development of bioclimatic chart for passive building design in Muscat-Oman. Int. J. Sustain. Energy 2012, 32, 713-723. [CrossRef]

41. Fanger, P.O. Thermal Comfort: Analysis and Applications in Environmental Engineering; Danish Technical Press: Copenhagen, Denmark, 1970.

42. Bell, P.; Green, T. Thermal Stress: Physiological, Comfort, Performance, and Social Effects of Hot and Cold Environments; Cambridge University: London, UK, 2008.

43. Fransson, N.; Västfjäll, D.; Skoog, J. In search of the comfortable indoor environment: A comparison of the utility of objective and subjective indicators of indoor comfort. Build. Environ. 2007, 42, 1886-1890. [CrossRef]

44. Orosa, J.A.; Armano, C.O. Passive Methods as a Solution for Improving Indoor Environments; Springer: London, UK, 2012.

45. Gauthier, M.S.; Shipworth, D. Predictive Thermal Comfort Model: Are Current Field Studies Measuring the most Influential Variables? In Proceedings of the 7th Windsor Conference: The Changing Context of Comfort in an Unpredictable World Cumberland Lodge, Windsor, UK, 12-15 April 2012; Network for Comfort and Energy Use in Buildings: London, UK, 2012.

46. AlOtaibi, M. The Effect of Ceiling Height on Thermal Comfort for Ceiling-Based Air Distribution Systems Vs Underfloor Air Distribution Systems in an Office Space. In Proceedings of the International Conference on Industrial Engineering and Operations Management, Paris, France, 26-27 July 2018; pp. 2453-2465.

47. Carlucci, A.; Pagliano, L. An Optimization Procedure Based on Thermal Discomfort. Minimization to Support the Design of Comfortable Net Zero Energy Buildings. In Proceedings of the BS2013: 13th Conference of International Building Performance Simulation Association, Chambéry, France, 26-28 August 2013; Network for Comfort and Energy Use in Buildings: Chambery, France, 2013; pp. 3690-3697.

48. International Standards Organization (ISO). Moderate Thermal Environments-Determination of the PMV and PPD Indices and Specification of the Conditions for Thermal Comfort; International Standards Organization: Geneva, Switzerland, 1984.

49. Andreasi, W.A.; Lamberts, R.; Candido, C. Thermal acceptability assessment in buildings located in hot and humid regions in Brazil. Build. Environ. 2010, 45, 1225-1232. [CrossRef]

50. Al-Ajmi, F.F. Thermal comfort in air-conditioned mosques in the dry desert climate. Build. Environ. 2010, 45, 2407-2413. [CrossRef]

51. Cheung, T.; Schiavon, S.; Parkinson, T.; Li, P.; Brager, G. Analysis of the accuracy on PMV—PPD model using the ASHRAE Global Thermal Comfort Database II. Build. Environ. 2019, 153, 205-217. [CrossRef]

52. Rasooli, A.; Itard, L. In-situ characterization of walls' thermal resistance: An extension to the ISO 9869 standard method. Energy Build. 2019, 179, 374-383. [CrossRef]

53. International Standards Organization (ISO/FDIS). Ergonomics of Thermal Environment-Analytical Determination and Interpretation of Thermal Comfort Using Calculation of the PMV and PPD Indices and Local Thermal Comfort Criteria; International Standards Organization: Geneva, Switzerland, 2005. 
54. Humphreys, M.; Fergus, N.; Roaf, S. Adaptive Thermal Comfort: Foundations and Analysis; Routledge, Taylor \& Francis Group: London, UK; New York, NY, USA, 2016.

55. Huang, C.; Zou, Z.; Li, M.; Wang, X.; Li, W.; Huang, W.; Yang, J.; Xiao, X. Measurements of indoor thermal environment and energy analysis in a large space building in typical seasons. Build. Environ. 2007, 42, 1869-1877. [CrossRef]

56. Krüger, E.; Givoni, B. Measurements of indoor thermal environment and energy analysis in a large space building in typical seasons. Build. Environ. 2007, 42, 431-435.

57. Hashimoto, Y.; Yoneda, H. Numerical study on the influence of a ceiling height. In Proceedings of the Eleventh International IBPSA Conference, Glasgow, Scotland, 27-30 July 2009.

58. Aflaki, A.; Mahyuddin, N.; Manteghi, G.; Baharum, M.R. Building height effects on indoor air temperature and velocity in high rise residential buildings in tropical climate. OIDA Int. J. Sustain. Dev. 2014, 7, 39-48.

59. Nobuo, M.; Kojima, S.; Yoko, T.; Kakon, A.N. Assessment of Thermal Comfort in Respect to Building Height in a High-Density City in the Tropics. Am. J. Eng. Appl. Sci. 2010, 3, 545-551.

60. Yang, Y.; Zhang, X.; Lu, X.; Hu, J.; Pan, X.; Zhu, Q.; Su, W. Effects of Building Design Elements on Residential Thermal Environment. Sustainability 2018, 10, 57. [CrossRef]

61. Dincyurek, O.; Mallick, F.H.; Numan, I. Cultural and environmental values in the arcaded Mesaorian houses of Cyprus. Build. Environ. 2003, 38, 1463-1473. [CrossRef]

62. Hansen, T.K.; Bjarløv, S.P.; Peuhkuri, R.H.; Harrestrup, M. Long term in situ measurements of hygrothermal conditions at critical points in four cases of internally insulated historic solid masonry walls. Energy Build. 2018, 172, 235-248. [CrossRef]

63. Halawa, E.; GhaffarianHoseini, A.; GhaffarianHoseini, A.; Trombley, J.; Hassan, N.; Baig, M.; Yusoff, S.Y.; Ismail, M.A. A review on energy conscious designs of building façades in hot and humid climates: Lessons for (and from) Kuala Lumpur and Darwin. Renew. Sustain. Energy Rev. 2018, 82, 2147-2161. [CrossRef]

64. La Gennusa, M.; Nucara, A.F.; Pietrafesa, M.; Rizzo, G. A model for managing and evaluating solar radiation for indoor thermal comfort. Sol. Energy 2007, 81, 594-606. [CrossRef]

65. Wu, F.; Zhu, J. Study on the construction of the database of energy-saving building wall's thermal performance in Hangzhou. Energy 2012, 14, 943-948. [CrossRef]

66. Radhi, H. Viability of autoclaved aerated concrete walls for the residential sector in the United Arab Emirates. Energy Build. 2011, 43, 2086-2092. [CrossRef]

67. Stazi, F.; Vegliò, A.; Di Perna, C.; Munafò, P. Experimental comparison between 3 different traditional wall constructions and dynamic simulations to identify optimal thermal insulation strategies. Energy Build. 2013, 60, 429-441. [CrossRef]

68. Hens, H.; Janssens, A.; Depraetere, W.; Carmeliet, J.; Lecompte, J. Brick Cavity Walls: A Performance Analysis Based on Measurements and Simulations. J. Build. Phys. 2007, 31, 95-124. [CrossRef]

69. Znouda, E.; Ghrab-Morcos, N.; Hadj-Alouane, A. Optimization of Mediterranean building design using genetic algorithms. Energy Build. 2007, 39, 148-153. [CrossRef]

70. Zhang, L.; Wang, Y. Shape optimization of free-form buildings based on solar radiation gain and space efficiency using a multi-objective genetic algorithm in the severe cold zones of China. Sol. Energy 2016, 132, 38-50. [CrossRef]

71. Neri, M.; Luscietti, D.; Fiorentino, A.; Pilotelli, M. Statistical Approach to Estimate the Temperature in Chimney Roof Penetration. Fire Technol. 2018, 54, 395-417. [CrossRef]

72. Neri, M.; Leppänen, P.; Bani, S.; Pentti, M.; Pilotelli, M. Experimental and Computational Study of the Temperatures Field Around a Chimney Roof Penetration. Fire Technol. 2016, 52, 1799-1823. [CrossRef]

73. Neri, M.; Lezzi, A.M.; Beretta, G.P.; Pilotelli, M. Energy- and Exergy-Based Analysis for Reducing Energy Demand in Heat Processes for Aluminum Casting. J. Energy Resour. Technol. 2019, 141, 104501-104513. [CrossRef]

74. Neri, M.; Pilotelli, M. Data on temperature-time curves measured at chimney-roof penetration. Data Brief. 2018, 20, 306-315. [CrossRef]

75. Ozel, M. Influence of glazing area on optimum thickness of insulation for different wall orientations. Appl. Therm. Eng. 2019, 147, 770-780. [CrossRef]

76. Ozel, M.; Pihtili, K. Optimum location and distribution of insulation layers on building walls with various orientations. Build. Environ. 2007, 42, 3051-3059. [CrossRef] 
77. Pekdogan, T.; Basaran, T. Thermal performance of different exterior wall structures based on wall orientation. Appl. Therm. Eng. 2017, 112, 15-24. [CrossRef]

78. Asan, H. Investigation of wall's optimum insulation position from maximum time lag and minimum decrement factor point of view. Energy Build. 2000, 32, 197-203. [CrossRef]

79. Bond, D.E.; Clark, W.W.; Kimber, M. Configuring wall layers for improved insulation performance. Appl. Energy 2013, 112, 235-245. [CrossRef]

80. Neri, M.; Ferrari, P.; Luscietti, D.; Pilotelli, M. Computational Analysis of the Influence of PCMs on Building Performance in Summer. In Energy Management of Municipal Transportation Facilities and Transport; Springer: Berlin/Heidelberg, Germany, 2018; pp. 3-15.

81. Sambou, V.; Lartigue, B.; Monchoux, F.; Adj, M. Thermal optimization of multilayered walls using genetic algorithms. Energy Build. 2009, 41, 1031-1036. [CrossRef]

82. Abanto, G.A.; Karkri, M.; Lefebvre, G.; Horn, M.; Solis, J.L.; Gómez, M.M. Thermal properties of adobe employed in Peruvian rural areas: Experimental results and numerical simulation of a traditional bio-composite material. Case Stud. Constr. Mater. 2017, 6, 177-191. [CrossRef]

83. Boostani, H.; Hancer, P. A Model for ExternalWalls Selection in Hot and Humid Climates. Sustainability 2019, $11,100$.

84. Dincyurek, O.; Turker, O.O. Learning from traditional built environment of Cyprus: Re-interpretation of the contextual values. Build. Environ. 2007, 42, 3384-3392. [CrossRef]

85. Census. Statistical Service. Available online: http://www.mof.gov.cy/mof/cystat/statistics.nsf/census-2011_ cystat_en/census-2011_cystat_en? (accessed on 28 April 2015).

86. Lotfabadi, P.; Emadi, B. Renewable Energies in Architecture. Tech. Mag. KCEDO 2011, 49-50, 77-81.

87. Eskin, N.; Türkmen, H. Analysis of annual heating and cooling energy requirements for office buildings in different climates in Turkey. Energy Build. 2008, 40, 763-773. [CrossRef]

88. Guo, W.; Nutter, D.W. Setback and setup temperature analysis for a classic double-corridor classroom building. Energy Build. 2010, 42, 189-197. [CrossRef]

89. Henninger, R.H.; Witte, M.J.; Crawley, D.B. Analytical and comparative testing of EnergyPlus using IEA HVAC BESTEST E100-E200 test suite. Energy Build. 2004, 36, 855-863. [CrossRef]

90. Sailor, D. A green roof model for building energy simulation programs. Energy Build. 2008, 40, 1466-1478. [CrossRef]

91. Zhai, Z.J.; Johnson, M.H.; Krarti, M. Assessment of natural and hybrid ventilation models in whole-building energy simulations. Energy Build. 2011, 43, 2251-2261. [CrossRef]

92. Oberkampf, W.L.; Trucano, T.G. Verification and validation in computational fluid dynamics. Prog. Aerosp. Sci. 2002, 38, 209-272. [CrossRef]

93. Baharvand, M.; Bin Ahmad, M.H.; Safikhani, T.; Binti Abdul Majid, R. DesignBuilder Verification and Validation for Indoor Natural Ventilation. J. Basic Appl. Sci. Res. 2013, 3, 182-189.

94. Fathalian, A.; Kargarsharifabad, H. Actual validation of energy simulation and investigation of energy management strategies (Case Study: An office building in Semnan, Iran). Case Stud. Therm. Eng. 2018, 12, 510-516. [CrossRef]

95. Famagusta Climate \& Temperature. Available online: www.famagusta.climatemps.com (accessed on 11 June 2019).

96. Brager, G. Mixed mode cooling. ASHRAE J. 2006, 48, 30-37.

(C) 2019 by the authors. Licensee MDPI, Basel, Switzerland. This article is an open access article distributed under the terms and conditions of the Creative Commons Attribution (CC BY) license (http://creativecommons.org/licenses/by/4.0/). 